\title{
9. BIOSTRATIGRAPHIC AND MAGNETOSTRATIGRAPHIC EVALUATION OF SITES 953, 954, 955, AND 956, CANARY ISLANDS ${ }^{1}$
}

\author{
C. Brunner, ${ }^{2}$ J. Sblendorio-Levy, ${ }^{3}$ R. Maniscalco, ${ }^{4}$ R. Howe, ${ }^{5}$ B. Herr, ${ }^{6}$ M. Fuller, ${ }^{7}$ P. Goldstrand, ${ }^{8}$ and P. van den Bogaard ${ }^{9}$
}

\begin{abstract}
Sequences from the volcanic apron of Gran Canaria of the Canary Islands were evaluated for continuity, steadiness of deposition rate, and age resolution to determine their fitness for study of geologic cycles through time. An age model was constructed using regression analysis of the polarity record for Site 953 , which had relatively complete magnetostratigraphy from the Brunhes Chron through the middle Miocene. Local ages for biostratigraphic datum levels were estimated from the polarity record at Site 953, and were used to construct age models for the other sites, where polarity records were highly discontinuous. The regression age models were refined using biostratigraphic and sedimentologic data to delimit hiatuses, slumps, and repeated sequences, and the accuracies of the age models were checked with radiometric dates where possible.

Local ages of foraminifer and calcareous nannofossil first and last occurrences were estimated from magnetostratigraphy of the sequence. Local ages of the first and last occurrences of most species do not differ significantly from current global/oceanwide ages, except those of nine species: the last occurrences of Globoquadrina dehiscens and Discoaster loeblichii and the first occurrences of Neogloboquadrina acostaensis, Globigerina nepenthes, Discoaster berggrenii, Minylitha convallis, Discoaster hamatus, Discoaster coalitus, and Discoaster kugleri. Hiatuses at the four sites generally group within four periods: the late Fataga eruptive period, the pre-Roque Nublo eruptive period, the Roque Nublo eruptive period, and the Late Pliocene and Quaternary Epochs, when changes in sea level were large and volcanic eruptions were sporadic on Gran Canaria.

Bio- and magnetostratigraphic evaluations of the Canary Island sites of Leg 157 clearly show that the section cored at Site 953 is the most continuous with the steadiest rates of sedimentation and the finest age resolution. Most bio- and magnetostratigraphic zones are present, and hiatuses last $<0.4 \mathrm{~m}$.y. Site 954 ranks second, but is flawed by several hiatuses $>1.0$ m.y. The best intervals at these sites, with standard errors of the age estimate $<0.1 \mathrm{~m} . \mathrm{y}$, are adequate to resolve the broad highs and lows of volcanic activity since the early middle Miocene, third-order sea-level changes, and broad environmental cycles, possibly even 0.4 m.y. Milankovitch cycles, but they are inadequate to resolve shorter cycles, like fourth-order sea-level changes, without improvement to the age models. By contrast, stratigraphic sequences at Sites 955 and 956 were generally unsuitable for time series studies requiring anything but crude age resolution over long intervals.
\end{abstract}

\section{INTRODUCTION}

One of the principal objectives of Leg 157 in the Canary Islands was to determine how well the geological history of a volcanic oceanic island is recorded in its flanking volcanic apron. Typically, ocean island history depends on the adequacy of land-based exposures. However, land-based exposures are frequently discontinuous in time and space, being either covered by young volcanic rocks or removed by erosion. Exposures are frequently over-represented by eruptive periods, whereas quiescent periods are poorly represented by sparse intervening sediments and unconformable surfaces. The volcanic apron of Gran Canaria was selected for study because the island's geologic history is well known from exceptional land-based

${ }^{1}$ Weaver, P.P.E., Schmincke, H.-U., Firth, J.V., and Duffield, W. (Eds.), 1998. Proc. ODP, Sci. Results, 157: College Station, TX (Ocean Drilling Program).

${ }^{2}$ Institute of Marine Sciences, University of Southern Mississippi, John C. Stennis Space Center, MS 39529, U.S.A. cbrunner@sunfish.st.usm.edu

${ }^{3} 6111$ Yarwell, Houston, TX 77096, U.S.A.

${ }^{4}$ Instituto di Geologia e Geofisica, Università di Catania, Corso, Italia 55, 95129 Catania, Italy.

${ }^{5}$ Challenger Division for Seafloor Processes, Southampton Oceanography Centre, Southampton, Hampshire SO14 3ZH, United Kingdom (Present address: Department of Geology and Geophysics, University of Western Australia, Nedlands WA 6907, Australia).

${ }^{6}$ Institut für Allgemeine und Angewandte Geophysik, Universität Munchen, Theresienstrasse, D-80333, München, Federal Republic of Germany.

${ }^{7}$ SOEST-Hawaii Institute of Geophysics and Planetology, University of Hawaii, Honolulu, Hawaii, 96822, U.S.A. (Present address: Department of Geological Sciences, University of California, Santa Barbara, CA 93106, U.S.A.)

${ }^{8}$ Department of Geological Sciences, University of Nevada, Reno, NV 89557, U.S.A.

${ }^{9}$ GEOMAR Forschungszentrum, Wischhofstrasse 1-3, D-241148 Kiel, Federal Republic of Germany. exposures (Schmincke, 1967, 1969, 1976, 1982, 1994; Schmincke and Sumita, Chap. 27, this volume; McDougall and Schmincke, 1977; Schmincke and von Rad, 1979; Staudigel and Schmincke, 1984). The island record can be used to test the adequacy of the volcanic apron as an historical repository.

The volcanic apron has other advantages. It receives not only island sedimentary debris, but also calcite marine microfossils because the apron stands above the regional calcite compensation depth (CCD). Island events therefore can be correlated to the marine record. The northern apron of Gran Canaria is sheltered from gravity slide deposits shed from the African continental margin, so clastic material is limited to that from Gran Canaria with minor contributions from adjacent volcanic islands. The southern apron, by contrast, receives gravity flows from the African continental margin, so continental events can be tied to island history. These correlations can be done, provided the record stored in the volcanic apron has the appropriate time resolution.

This paper examines the adequacy of the volcanic-apron record by exploring its stratigraphic completeness, continuity, and time resolution, all of which are essential to determining its potential sensitivity to the timing of eruptive and quiescent phases of island volcanism, third- and fourth-order sea-level changes, cycles in regional and global climate, and other geologic cycles through time. The apron is composed of many turbidites, debris flows, tephra layers, slumps, and thick volcaniclastic deposits interlayered with pelagites, hence completeness, continuity, and time resolution of the depositional record are looming questions.

The approach used here was to construct sediment accumulation regression models of age vs. depth using available magnetostratigraphic and biostratigraphic events. Regression lines were calculated using ages and depths of magneto- and/or biostratigraphic events, but 
other methods of determining a quantitative relationship might also be useful, such as graphic correlation (see Dowsett, 1989). Stratigraphic error was included in the estimate by entering both the sample where the microfossil first or last occurred and the neighboring sample where it did not occur (= stratigraphic error), and an analogous stratigraphic error was included in the polarity events. The models were evaluated to detect hiatuses and other disruptions to sedimentation and to delimit continuous sequences within the resolution of the biostratigraphy. Continuous sequences were evaluated for time resolution, and where possible, radiometric dates were used as an independent check of model accuracy.

\section{SITE 953 AND DEVELOPMENT OF AN AGE MODEL Description of Site 953}

Site 953 has the most continuous sedimentary sequence of all the sites on the volcanic apron of Gran Canaria. The sequences above 889 meters below seafloor (mbsf) consist of $\sim 60 \%$ pelagites (by length in core) interlayered with many turbidites and occasional larger downslope deposits, such as debris flows, slumps, and lapillistones (Fig. 1). Below 889 mbsf, facies coarsen where basaltic sandstone, lapillistone, breccia, and hyaloclastite tuffs dominate lithostratigraphic Units VI and VII (Shipboard Scientific Party, 1995a). Most bio- and magnetostratigraphic samples were taken from pelagites, except in lithostratigraphic Units VI and VII, where pelagite clasts were sampled from the breccia units, and pelagic-looking units were sampled from the tops of coarse volcaniclastic turbidites.
Essentially all calcareous nannofossil zones (Fig. 2) were identified at Site 953 from Quaternary Zone CN15 to early middle Miocene to late early Miocene Zone CN3 at 1153.21 mbsf, near the base of the hole, although resolution of nannofossil zonal boundaries is poor below 889 mbsf, where volcaniclastic sands dominate (SblendorioLevy and Howe, Chap. 8, this volume). All planktonic foraminifer zones were recognized from Quaternary Zone PT1b to earliest Pliocene Zone PL1 as defined by Berggren et al. (1995b), although some tropical species were excluded from the temperate to cool subtropical waters of those times. By contrast, environmental exclusion of tropical species from cool subtropical waters interfered with zonal assignments of Miocene-age material. Zones M13 to M11 were recognized only after modifications of the zonal definitions. Poor microfossil preservation resulted because a worldwide shallowing of the CCD interfered with the zonation of the middle Miocene (Heath, 1969; Berger and von Rad, 1972; Berger and Winterer, 1974; van Andel and Moore, 1974; van Andel, 1975; van Andel et al., 1975; Ramsay, 1977; Thunell, 1981). The sequence from 497 to $540 \mathrm{mbsf}$ was assigned to undifferentiated Zones M9/M10, and the deepest zoned samples from 543 to 556 mbsf were assigned to an undifferentiated Zone M8 or older (Maniscalco and Brunner, Chap. 10, this volume). Foraminifers were observed in thin sections of lithified pelagite clasts in breccia below 889 mbsf, but the microfossils were not identified.

The polarity record at Site 953 (Table 1; Fig. 2) is excellent and nearly complete from the Quaternary to the lower middle Miocene in the fine-grained pelagites of the holes, but is unresolved in the coarsegrained deposits of lithostratigraphic Units VI and VII below 889

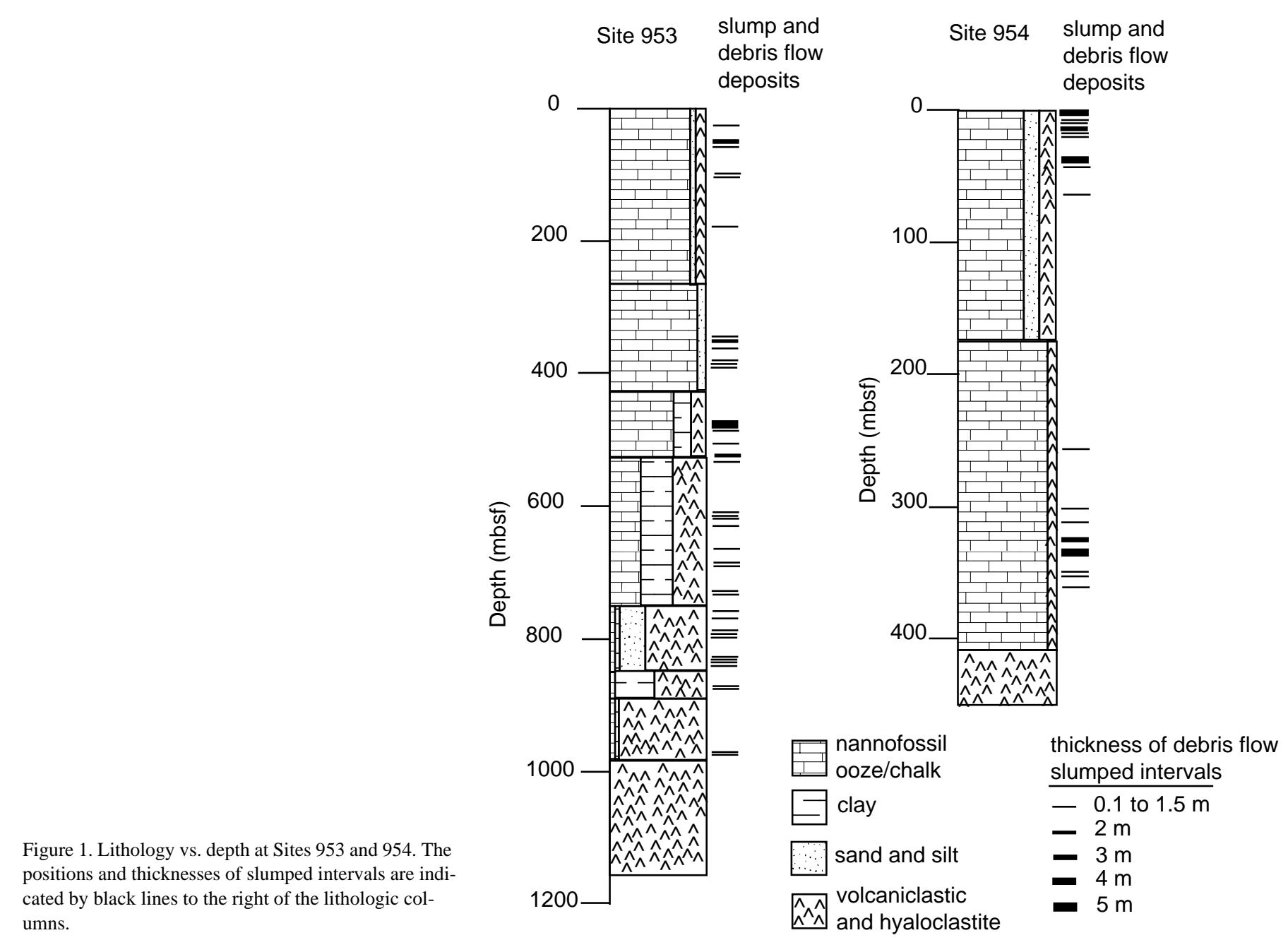




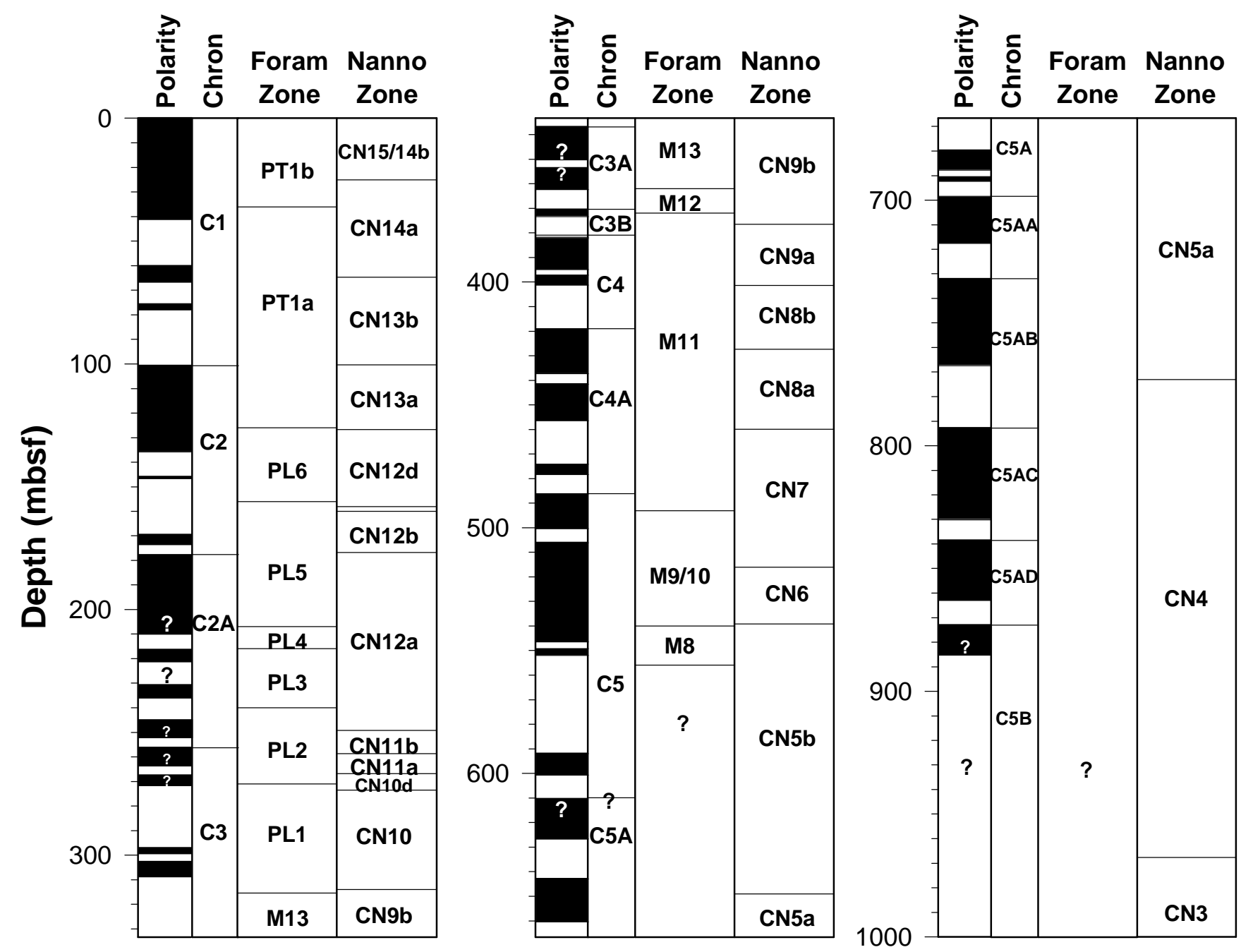

Figure 2. Correlation of bio- and magnetostratigraphic zones at Site 953.

mbsf (B. Herr and M. Fuller, pers. comm., 1996). There are additional, but remarkably few problems with the record above $889 \mathrm{mbsf}$. Strong disturbance associated with rotary drilling at the top of Hole 953C was blamed for the failure to recover the base of the Kaena, the top of the Mammoth, the base of the Cochiti, the top of the Nunivak, and the base of the Sidjufall Subchrons, and the base of the Mammoth subchron could only be bracketed within a 10-m-long interval. Fortunately, increased lithification below these subchrons diminished disturbance caused by rotary drilling. The base of C3An.n1 and the top of C3An.n2 were apparently removed by slumping, but the remainder of the polarity record was faithfully recorded to the top of Subchron C5Bn.1n, 14.8 Ma (B. Herr and M. Fuller, pers. comm., 1996).

\section{Age Model}

An age model for sediment accumulation was constructed based on the polarity record of B. Herr and M. Fuller (pers. comm., 1996) and the time scale of Berggren et al. (1995b), although there are several other recent time scales that could have been applied (e.g., Cande and Kent, 1995; Shackleton et al., 1995). A plot of ages of subchron boundaries vs. depths below seafloor (Table 1, Fig. 3) shows that the sedimentation rates are remarkably linear over five discrete segments calculated by linear regression (Fig. 3; Table 2). Inspection of the lines shows that two junctions are offset, suggesting small disconfor- mities. One offset between 264.11 and $264.82 \mathrm{mbsf}$ falls within a slump that apparently removed a minimum of 0.2 m.y. of sediment between the first occurrence of Globorotalia miocenica and the last occurrence of Globigerina nepenthes at 4.24-4.35 and 4.41-4.55 Ma. The duration of the hiatus is 0.6 m.y., based on the extension of the regression lines through the subchron boundaries to the top and bottom of the slump. The disconformity lies at the top of Hole 953C, which was plagued by poor sediment recovery that might have contributed to the loss of sediment. The second offset between 505.90 and $516.07 \mathrm{mbsf}$ is associated with a debris flow between 504.1 and 506.85 mbsf that might have caused the disconformity. A minimum of 0.38 m.y. was lost between the top of Subchron C $5 n .2 n$ and the first occurrence of Discoaster hamatus at 9.82 and 10.2 Ma, respectively. The duration of the hiatus was 0.3 m.y., based on extension of the regression lines through the subchron boundaries to the top and bottom of the debris flow. A disconformity also occurs at the top of Site 953 . The sequence is missing the first 0.2 m.y. of deposition based on the first occurrence of Globigerina calida calida at $0.2-0.22$ $\mathrm{Ma}$ in the core-top sample and by the presence of a turbidite at the top of the sequence. The duration of the hiatus is also 0.2 m.y., based on extrapolation of the regression line through the Quaternary and late Pliocene subchron boundaries to the top of the sequence.

The age model was compared to radiometric dates in the sequence as an independent check of its accuracy (Table 3; Fig. 3). Potassium feldspar from ash fallout layers, tephra-rich turbidites, lapillistone 
Table 1. Magnetostratigraphy of Site 953.

\begin{tabular}{|c|c|c|c|c|c|c|c|}
\hline \multirow[b]{2}{*}{ Chrons } & \multirow[b]{2}{*}{ Name } & \multirow[b]{2}{*}{ Code } & \multirow[b]{2}{*}{$\begin{array}{l}\text { Age } \\
\text { (Ma) }\end{array}$} & \multicolumn{2}{|l|}{ Top } & \multicolumn{2}{|c|}{ Bottom } \\
\hline & & & & $\begin{array}{l}\text { Core, section, } \\
\text { depth }(\mathrm{cm})\end{array}$ & $\begin{array}{l}\text { Depth } \\
\text { (mbsf) }\end{array}$ & $\begin{array}{l}\text { Core, section, } \\
\text { depth }(\mathrm{cm})\end{array}$ & $\begin{array}{l}\text { Depth } \\
\text { (mbsf) }\end{array}$ \\
\hline $\mathrm{C} \ln (\mathrm{o})$ & Brunhes/Matuyama & 89 & 0.78 & $5 \mathrm{H}-4,55$ & 41.1 & $5 \mathrm{H}-4,65$ & 41.3 \\
\hline C1r.1n $(t)$ & Jaramillo (t) & 90 & 0.99 & $7 \mathrm{H}-4,15$ & 59.8 & $7 \mathrm{H}-4,65$ & 60.3 \\
\hline C1r. $\ln (\mathrm{o})$ & Jaramillo (o) & 91 & 1.07 & $8 \mathrm{H}-1,75$ & 65.3 & $8 \mathrm{H}-3,55$ & 68.0 \\
\hline Clr.2n (t) & Cobb Mtn (t) & 92 & 1.20 & $9 \mathrm{H}-1,150$ & 75.3 & $9 \mathrm{H}-2,5$ & 75.7 \\
\hline C1r.2n (o) & CobbMtn (o) & 93 & 1.21 & $9 \mathrm{H}-3,85$ & 77.9 & $9 \mathrm{H}-3,95$ & 78.0 \\
\hline $\mathrm{C} 2 \mathrm{n}(\mathrm{t})$ & Olduvai $(\mathrm{t})$ & 94 & 1.77 & $12 \mathrm{H}-1,15$ & 100.6 & $12 \mathrm{H}-2,34$ & 100.8 \\
\hline $\mathrm{C} 2 \mathrm{n}(\mathrm{o})$ & Olduvai (o) & 95 & 1.95 & $15 \mathrm{H}-3,95$ & 135.0 & $15 \mathrm{H}-4,95$ & 136.6 \\
\hline $\mathrm{C} 2 \mathrm{r} \cdot \ln (\mathrm{t})$ & Reunion (t) & 96 & 2.14 & $16 \mathrm{H}-4,75$ & 145.8 & $16 \mathrm{H}-4,85$ & 146.0 \\
\hline C2r.1n (o) & Reunion (o) & 97 & 2.15 & $16 \mathrm{H}-5,15$ & 146.6 & $16 \mathrm{H}-5,25$ & 146.8 \\
\hline $\mathrm{C} 2 \mathrm{r} .2 \mathrm{n}(\mathrm{t})$ & & 98 & 2.42 & $18 \mathrm{H}-7,75$ & 169.4 & $19 \mathrm{H}-1,45$ & 169.6 \\
\hline C2r.2n (o) & & 99 & 2.44 & $19 \mathrm{H}-3,71$ & 172.8 & $19 \mathrm{H}-4,84$ & 174.4 \\
\hline $\mathrm{C} 2 \mathrm{An}(\mathrm{t})$ & Matuyama / Gauss & 100 & 2.60 & $19 \mathrm{H}-6,95$ & 177.6 & $19 \mathrm{H}-6,105$ & 177.7 \\
\hline $\mathrm{C} 2 \mathrm{An} . \operatorname{lr}(\mathrm{t})$ & Kaena $(t)$ & 102 & 3.04 & $5 \mathrm{R}-1,35$ & 216.2 & $5 \mathrm{R}-1,45$ & 216.3 \\
\hline C2An.1r (o) & Kaena (o) & & 3.13 & i & 20.2 & (1) & 1 \\
\hline $\mathrm{C} 2 \mathrm{An} \cdot 2 \mathrm{r}(\mathrm{t})$ & Mammoth (t) & & 3.22 & i & 1 & I & I \\
\hline $\mathrm{C} 2 \mathrm{An} \cdot 2 \mathrm{r}(\mathrm{o})$ & Mammoth (o) & 103 & 3.33 & $6 \mathrm{R}-1,72$ & 226.2 & $7 \mathrm{R}-1,5$ & 235.1 \\
\hline $\mathrm{C} 2 \mathrm{Ar}(\mathrm{t})$ & Gauss / Gilbert & 104 & 3.59 & $8 \mathrm{R}-1,15$ & 244.8 & $8 \mathrm{R}-1,25$ & 244.9 \\
\hline $\mathrm{C} 3 \mathrm{n} \cdot \ln (\mathrm{t})$ & Cochiti (t) & 105 & 4.20 & $9 \mathrm{R}-2,37$ & 256.0 & $9 \mathrm{R}-3,82$ & 256.4 \\
\hline C3n.1n (o) & Cochiti (o) & & 4.32 & 1 & I & i & 1 \\
\hline C $3 n .2 n(t)$ & Nunivak (t) & & 4.48 & 1 & i & 1 & 1 \\
\hline C $3 n .2 n(o)$ & Nunivak (o) & 106 & 4.62 & $10 \mathrm{R}-3,95$ & 267.7 & $11 \mathrm{R}-2,95$ & 275.8 \\
\hline $\mathrm{C} 3 \mathrm{n} \cdot 3 \mathrm{n}(\mathrm{t})$ & Sidjufall (t) & 107 & 4.78 & $13 \mathrm{R}-3,150$ & 296.9 & I & 1 \\
\hline C3n.3n (o) & Sidjufall (o) & 108 & 4.88 & 1 & ' & 13R-5, 65 & 299.4 \\
\hline C $3 n \cdot 4 n(t)$ & Thvera $(\mathrm{t})$ & 109 & 4.98 & $14 \mathrm{R}-1,115$ & 302.6 & 1 & 1 \\
\hline C $3 n .4 n(o)$ & Thvera (o) & 110 & 5.23 & $14 \mathrm{R}-2,125$ & 305.2 & $15 \mathrm{R}-1,15$ & 312.3 \\
\hline C3An. $\ln (\mathrm{t})$ & Hitvera $(0)$ & 111 & 5.88 & $17 \mathrm{R}-4,115$ & 336.7 & 17R-4, 125 & 336.9 \\
\hline C 3 An. 1 n (o) & & & 6.12 & & 1 & & 1 \\
\hline C $3 A n \cdot 2 n(t)$ & & & 6.26 & 1 & 1 & I & 1 \\
\hline C3An.2n (o) & & 112 & 6.56 & 20R-2, 95 & 362.3 & 20R-2, 105 & 362.4 \\
\hline $\mathrm{C} 3 \mathrm{Bn}(\mathrm{t})$ & & 113 & 6.92 & $21 \mathrm{R}-1,75$ & 370.2 & $21 \mathrm{R}-1,115$ & 370.6 \\
\hline C3Bn (o) & & 114 & 7.07 & $21 \mathrm{R}-3,75$ & 373.3 & $21 \mathrm{R}-3,85$ & 373.4 \\
\hline $\mathrm{C} 4 \mathrm{n} \cdot 1 \mathrm{n}(\mathrm{t})$ & & 115 & 7.41 & 22R-2, 15 , & 380.8 & $22 \mathrm{R}-2,25$ & 380.9 \\
\hline C 4 n. $\ln (\mathrm{o})$ & & 116 & 7.53 & 22R-2, 105 & 381.7 & $22 \mathrm{R}-2,115$ & 381.7 \\
\hline $\mathrm{C} 4 \mathrm{n} \cdot 2 \mathrm{n}(\mathrm{t})$ & & 117 & 7.62 & $22 \mathrm{R}-2,145$ & 382.1 & $22 \mathrm{R}-3,15$ & 382.3 \\
\hline C4n.2n (o) & & 118 & 8.03 & $23 \mathrm{R}-5,15$, & 394.8 & $23 \mathrm{R}-5,25$ & 394.9 \\
\hline $\mathrm{C} 4 \mathrm{r} \cdot \ln (\mathrm{t})$ & & 119 & 8.17 & $23 \mathrm{R}-6,145$ & 396.1 & $24 \mathrm{R}-1,25$ & 398.4 \\
\hline C4r.1n (o) & & 120 & 8.21 & $24 \mathrm{R}-3,15$ & 401.2 & $24 \mathrm{R}-3,25$ & 401.4 \\
\hline $\mathrm{C} 4 \mathrm{An}(\mathrm{t})$ & & 121 & 8.63 & $26 \mathrm{R}-2,15$ & 418.9 & $26 \mathrm{R}-2,25$ & 419.0 \\
\hline C4An (o) & & 122 & 8.95 & $28 \mathrm{R}-1,35$ & 437.0 & $28 \mathrm{R}-1,95$ & 437.6 \\
\hline C4Ar.1n (t) & & 123 & 9.14 & $28 \mathrm{R}-4,25$ & 441.4 & $28 \mathrm{R}-4,65$ & 441.7 \\
\hline C4Ar.1n (o) & & 124 & 9.22 & 30R-1, 45 & 456.4 & $30 \mathrm{R}-1,55$ & 456.4 \\
\hline C4Ar.2n (t) & & 125 & 9.48 & $31 \mathrm{R}-4,145$ & 471.4 & $32 \mathrm{R}-2,15$ & 476.9 \\
\hline C4Ar.2n (o) & & 126 & 9.54 & $32 \mathrm{R}-3,15$ & 478.3 & $32 \mathrm{R}-3,25$ & 478.4 \\
\hline C5n.1n $(\mathrm{t})$ & & 127 & 9.64 & $33 \mathrm{R}-1,75$ & 485.6 & $33 \mathrm{R}-2,45$ & 486.8 \\
\hline C $5 \mathrm{n} .1 \mathrm{n}(\mathrm{o})$ & & 128 & 9.78 & $34 \mathrm{R}-4,15$ & 499.2 & $34-\mathrm{R} 5,145$ & 501.6 \\
\hline C $5 n .2 n(t)$ & & 129 & 9.82 & $35 \mathrm{R}-2,45$ & 505.9 & $35 \mathrm{R}-2,105$ & 506.5 \\
\hline C5n.2n (o) & & 130 & 10.84 & $39 \mathrm{R}-3,105$ & 546.5 & $39 \mathrm{R}-3,115$ & 546.6 \\
\hline C5r.1n (t) & & 131 & 10.94 & $39 \mathrm{R}-5,95$ & 549.2 & $39 \mathrm{R}-5,105$ & 549.3 \\
\hline C5r.1n (o) & & 132 & 10.99 & $39 \mathrm{R}-6,135$ & 550.9 & $40 \mathrm{R}-1,55$ & 553.0 \\
\hline C5r.2n (t) & & 133 & 11.37 & $44 \mathrm{R}-1,95$ & 591.6 & $44 \mathrm{R}-2,25$ & 592.4 \\
\hline C $5 \mathrm{r} .2 \mathrm{n}(\mathrm{o})$ & & 134 & 11.43 & $45 \mathrm{R}-1,25$ & 600.7 & 1 & 1 \\
\hline $\mathrm{C} 5 \mathrm{An} .1 \mathrm{n}(\mathrm{t})$ & & & 11.84 & I & 1 & 1 & I \\
\hline C5An.1n (o) & & 135 & 11.99 & $47 \mathrm{R}-4,45$ & 623.5 & $48 \mathrm{R}-1,45$ & 629.8 \\
\hline $\mathrm{C} 5 \mathrm{An} \cdot 2 \mathrm{n}(\mathrm{t})$ & & 136 & 12.10 & $49 \mathrm{R}-3,115$ & 642.9 & $49 \mathrm{R}-3,125$ & 643.0 \\
\hline C $5 \mathrm{An} .2 \mathrm{n}(\mathrm{o})$ & & 137 & 12.32 & $51 \mathrm{R}-2,115$ & 660.4 & $51 \mathrm{R}-2,125$ & 660.5 \\
\hline C5Ar.1n.(t) & & 138 & 12.61 & $53 \mathrm{R}-2,55$ & 679.4 & $53 \mathrm{R}-2,95$ & 679.8 \\
\hline C5Ar.1n.(o) & & 139 & 12.64 & $54 \mathrm{R}-1,35$ & 687.4 & $54 \mathrm{R}-1,115$ & 688.2 \\
\hline C 5 Ar.2n (t) & & 140 & 12.71 & $54 \mathrm{R}-3,65$ & 690.3 & $54 \mathrm{R}-3,95$ & 690.6 \\
\hline C5Ar.2n (o) & & 141 & 12.75 & $54 \mathrm{R}-4,75$ & 691.9 & $54 \mathrm{R}-5,25$ & 692.9 \\
\hline C5AAn $(\mathrm{t})$ & & 142 & 12.93 & $55 \mathrm{R}-2,15$, & 697.9 & $55 \mathrm{R}-3,5$ & 699.1 \\
\hline C5AAn (o) & & 143 & 13.08 & $57 \mathrm{R}-2,55$ & 717.5 & $57 \mathrm{R}-2,65$ & 717.6 \\
\hline C5ABn (t) & & 144 & 13.25 & $58 \mathrm{R}-5,75$ & 731.8 & 58R-5, 105 & 732.1 \\
\hline C5ABn (o) & & 145 & 13.47 & $62 \mathrm{R}-3,15$ & 766.7 & $62 \mathrm{R} 4,5$ & 768.1 \\
\hline $\mathrm{C} 5 \mathrm{ACn}(\mathrm{t})$ & & 146 & 13.67 & $65 \mathrm{R}-1,35$ & 792.7 & $65 \mathrm{R}-1,45$ & 792.8 \\
\hline C5ACn (o) & & 147 & 14.05 & $68 \mathrm{R}-4,115$ & 826.7 & $69 \mathrm{R}-2,115$ & 833.7 \\
\hline C5ADn (t) & & 148 & 14.16 & $69 \mathrm{R}-4,85$ & 836.2 & $70 \mathrm{R}-1,5$ & 840.9 \\
\hline C5ADn (o) & & 149 & 14.61 & $72 \mathrm{R}-2,85$ & 862.5 & $72 \mathrm{R}-3,65$ & 863.5 \\
\hline $\mathrm{C} 5 \mathrm{Bn} .1 \mathrm{n}(\mathrm{t})$ & & 150 & 14.80 & 73R-2, 115 & 872.4 & $73 \mathrm{R}-3,95$ & 873.7 \\
\hline
\end{tabular}

Notes: Polarity record from B. Herr and M. Fuller (pers. comm., 1996). Timescale from Berggren et al. $(1995 b)$. $(t)=$ termination, $(\mathrm{o})=$ onset, and $/=$ not found.

breccia deposits, and debris flows were dated by single crystal laser ${ }^{40} \mathrm{Ar} /{ }^{39} \mathrm{Ar}$ analysis (Bogaard, Chap. 19, this volume). In the Quaternary sequence, four dates ranging from 0.246 to $1.83 \mathrm{Ma}$ (Bogaard, Chap. 19, this volume) fall within the $95 \%$ confidence interval of the regression age model line. However, three dates from syn-ignimbrite turbidites that were correlated to dated land-based ignimbrites from the middle Miocene (Bogaard and Schmincke, Chap. 11; Sumita and Schmincke, Chap. 15; both this volume), were consistently and significantly younger than the model estimates by $0.31-0.46$ m.y., suggesting that biostratigraphic and magnetostratigraphic control was either degraded within the coarse deposits that characterize the base of the sequence, or the ages assigned to datum levels between 13 and 14 Ma are too old and need revision (Schmincke and Sumita, Chap. 27, this volume).

Sedimentation rates were estimated from the regression equations at $95 \%$ confidence intervals (Table 2). Wider ranges in rates suggest greater stratigraphic uncertainty. Sedimentation rates were fast, ranging between 87 and $93 \mathrm{~m} / \mathrm{m}$.y. from 15 to $11 \mathrm{Ma}$ during eruption of the Mogan and lower Fataga groups $(114 \mathrm{~m} / \mathrm{m}$.y., based on radiometric dates), slowed to a range of 67 to $81 \mathrm{~m} / \mathrm{m}$.y. from 10 to $8.6 \mathrm{Ma}$ during eruption of the upper Fataga group, and slowed to a minimum range of 21 to $24 \mathrm{~m} / \mathrm{m}$.y. from 8.6 to 6.0 Ma during the early part of 


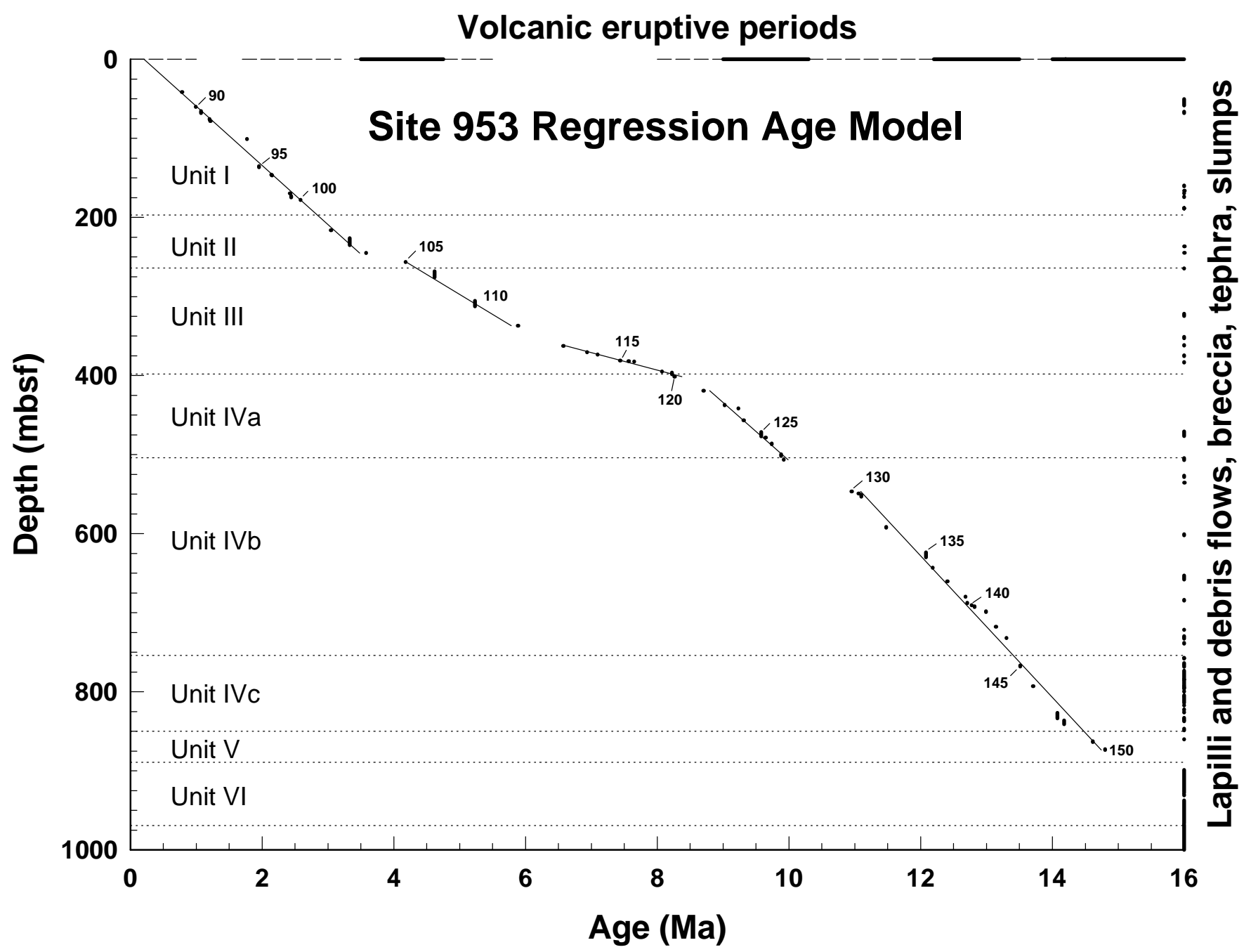

Figure 3. Age model of the sequence at Site 953. The five thin-black-line segments are fitted to polarity events (depths from B. Herr and M. Fuller, pers. comm., 1996; time scale from Berggren et al., 1995b) using least-squares regression with age as the dependent variable and depth (mbsf) as the independent variable (Tables 1,2). The numbers identify the magnetostratigraphic boundaries as coded in Table 1. The timing of volcanic eruptive periods on Gran Canaria is plotted on the secondary age axis, and the depths of lapillistones, debris flows, breccia, slumps and other coarse-grained deposits are plotted on the secondary depth axis. The boundaries of the lithostratigraphic units are marked as dashed horizontal dashed lines.

the major nonvolcanic phase on Gran Canaria ( 9 to $5 \mathrm{Ma}$; see Schmincke and Sumita, Chap. 27, this volume, for definition of this period). Rates increased to a range of 44 to $61 \mathrm{~m} / \mathrm{m}$.y. from 6.0 to 4.36 Ma during the end of the major nonvolcanic phase and the early eruptions of the Roque Nublo group, and increased again from 72 to 77 $\mathrm{m} / \mathrm{m}$.y. (69 m/m.y., based on radiometric dates) between 3.7 and 0.2 Ma during the end of the Roque Nublo eruptions, the late Pliocene events, and the late Quaternary events.

\section{Estimated Ages of Local First and Last Occurrences of Species}

Our objective was to construct an age model based on magnetostratigraphy of the sequence at Site 953 that could be applied to the other Canary Island sequences where magnetostratigraphy is incomplete or entirely lacking, but where microfossil datum levels are plentiful. The first step was to determine the local ages of calcareous nannofossil and foraminifer datum levels using the magnetostratigraphy of Site 953 (B. Herr and M. Fuller, pers. comm., 1996). A plot of depth vs. age (Berggren et al., 1995a, 1995b) of microfossil first and last occurrences in the sequence was superimposed onto the age vs. depth plot of subchron boundaries (Fig. 4). Maniscalco and Brunner (Chap. 10, this volume) estimated local ages of foraminifer events (Table 4) by calculating the ages estimated by the regression equations that model age-depth relations at Site 953 (Table 2). In contrast, Sblendorio-Levy and Howe (Chap. 8, this volume) estimated local ages by projecting nannofossil events onto the lines formed by connecting each subchron boundary (Table 5). Figure 2 shows that differences between the two approaches are small. Each approach has merit, and it is beyond the scope of this synthesis paper to favor one over the other.

In most instances, ages of local first and last occurrences differ only slightly from global or oceanwide ages of Berggren et al. (1995a, 1995b) and fall close to the age vs. depth plot of polarity events (Figs. 3, 4). Datum levels most different in age from those of Berggren et al. (1995a, 1995b) are the last occurrence of Globoquadrina dehiscens, the first occurrence of Neogloboquadrina acostaensis, the first occurrence of G. nepenthes, the last occurrence of Discoaster loeblichii, the first occurrence of Discoaster berggrenii, the first occurrence of Minylitha convallis, the first occurrence of $D$. 
Table 2. Parameters and terms calculated in four regression age models of Sites 953, 954, 955, and 956.

\begin{tabular}{|c|c|c|c|c|c|}
\hline Equation & 1 & 2 & 3 & 4 & 5 \\
\hline $\begin{array}{l}\text { Site } 953 \text { model } \\
\text { Depth (mbsf) } \\
\text { Constant (m.y.) } \\
\text { Standard error of age estimate of age est (m.y.) } \\
\text { R squared } \\
\text { Number of observations } \\
\text { Degrees of freedom } \\
\text { X coefficient }(\mathrm{s}) \\
\text { Standard error of coefficient } \\
\text { Sedimentation rate }(\mathrm{m} / \mathrm{m} . \mathrm{y} .) \\
\text { T }(95 \%) \\
95 \% \text { confidence interval, bottom } \\
95 \% \text { confidence interval, top }\end{array}$ & $\begin{array}{l}0.0-264.11 \\
0.202550 \\
0.078218 \\
0.992038 \\
30 \\
28 \\
0.013386 \\
0.000227 \\
74.7 \\
2.048 \\
72.2 \\
77.4\end{array}$ & $\begin{array}{c}264.82-349.09 \\
-0.880749 \\
0.128735 \\
0.955034 \\
11 \\
9 \\
0.019772 \\
0.001430 \\
50.6 \\
2.262 \\
43.5 \\
60.5\end{array}$ & $\begin{array}{l}349.09-407.39 \\
-9.672381 \\
0.076844 \\
0.983155 \\
18 \\
16 \\
0.044957 \\
0.001471 \\
22.2 \\
2.12 \\
20.8 \\
23.9\end{array}$ & $\begin{array}{l}407.39-505.90 \\
3.108399 \\
0.066594 \\
0.973852 \\
18 \\
16 \\
0.013585 \\
0.000556 \\
73.6 \\
2.101 \\
67.8 \\
80.5\end{array}$ & $\begin{array}{l}516.07-873.7 \\
4.989103 \\
0.117007 \\
0.989551 \\
41 \\
39 \\
0.011164 \\
0.000184 \\
89.6 \\
2.021 \\
86.7 \\
92.7\end{array}$ \\
\hline $\begin{array}{l}\text { Site } 954 \text { model } \\
\text { Depth (mbsf) } \\
\text { Constant (m.y.) } \\
\text { Standard error of age estimate (m.y.) } \\
\text { R squared } \\
\text { Number of observations } \\
\text { Degrees of freedom } \\
\text { X coefficient(s) } \\
\text { Standard error of coefficient } \\
\text { Sedimentation rate (m/m.y.) } \\
\text { t }(95 \%) \\
95 \% \text { confidence interval, bottom } \\
95 \% \text { confidence interval, top }\end{array}$ & $\begin{array}{c}0.0-77.32 \\
0.158506 \\
0.081665 \\
0.879142 \\
12 \\
10 \\
0.011830 \\
0.001387 \\
84.5 \\
2.228 \\
67.0 \\
114.4\end{array}$ & $\begin{array}{c}109.7-241.56 \\
0.420451 \\
0.192940 \\
0.938857 \\
26 \\
24 \\
0.018351 \\
0.000956 \\
54.5 \\
2.064 \\
49.2 \\
61.1\end{array}$ & $\begin{array}{l}241.56-273.86 \\
-6.186008 \\
0.232098 \\
0.880055 \\
10 \\
8 \\
0.045701 \\
0.005965 \\
21.9 \\
2.306 \\
16.8 \\
31.3\end{array}$ & $\begin{array}{c}273.86-377.83 \\
-0.070646 \\
0.106334 \\
0.981033 \\
26 \\
24 \\
0.023371 \\
0.000663 \\
42.8 \\
2.064 \\
40.4 \\
45.5\end{array}$ & $\begin{array}{l}- \\
- \\
- \\
z \\
- \\
- \\
-\end{array}$ \\
\hline $\begin{array}{l}\text { Site } 955 \text { model } \\
\text { Depth (mbsf) } \\
\text { Constant (m.y.) } \\
\text { Standard error of age estimate (m.y.) } \\
\text { R squared } \\
\text { Number of observations } \\
\text { Degrees of freedom } \\
\text { X coefficient(s) } \\
\text { Standard error of coefficient } \\
\text { Sedimentation rate (m/m.y.) } \\
\text { t } 95 \%) \\
95 \% \text { confidence interval, bottom } \\
95 \% \text { confidence interval, top }\end{array}$ & $\begin{array}{c}0.0-93.6 \\
-0.009488 \\
0.050388 \\
0.990346 \\
12 \\
10 \\
0.016262 \\
0.000508 \\
61.5 \\
2.228 \\
57.5 \\
66.1\end{array}$ & $\begin{array}{l}- \\
- \\
- \\
z \\
- \\
- \\
-\end{array}$ & $\begin{array}{c}272.56-364 \\
-0.583872 \\
0.628098 \\
0.631883 \\
9 \\
7 \\
0.024401 \\
0.007039 \\
41.0 \\
2.365 \\
24.4 \\
129.0\end{array}$ & $\begin{array}{l}420.0-487.55 \\
-1.546709 \\
0.495921 \\
0.647859 \\
14 \\
12 \\
0.027596 \\
0.005873 \\
36.2 \\
2.179 \\
24.8 \\
67.6\end{array}$ & $\begin{array}{l}- \\
- \\
- \\
z \\
- \\
- \\
-\end{array}$ \\
\hline $\begin{array}{l}\text { Site } 956 \text { model } \\
\text { Depth (mbsf) } \\
\text { Constant (m.y.) } \\
\text { Standard error of age estimate (m.y.) } \\
\text { R squared } \\
\text { Number of observations } \\
\text { Degrees of freedom } \\
\text { X coefficient(s) } \\
\text { Standard error of coefficient } \\
\text { Sedimentation rate (m/m.y.) } \\
\text { t }(95 \%) \\
95 \% \text { confidence interval, bottom } \\
95 \% \text { confidence interval, top }\end{array}$ & $\begin{array}{l}- \\
- \\
- \\
- \\
- \\
- \\
-\end{array}$ & $\begin{array}{l}33.26-96.9 \\
0.777394 \\
0.178858 \\
0.821139 \\
20 \\
18 \\
0.020377 \\
0.002242 \\
49.1 \\
2.101 \\
39.9 \\
63.8\end{array}$ & $\begin{array}{c}159.82-270 \\
-0.516236 \\
0.435947 \\
0.940779 \\
16 \\
14 \\
0.024268 \\
0.001627 \\
41.2 \\
2.145 \\
36.0 \\
48.1\end{array}$ & $\begin{array}{c}354.31-513.8 \\
-6.830321 \\
0.645658 \\
0.863044 \\
22 \\
20 \\
0.038974 \\
0.003472 \\
25.7 \\
2.086 \\
21.6 \\
31.5\end{array}$ & $\begin{array}{l}- \\
- \\
- \\
- \\
- \\
- \\
-\end{array}$ \\
\hline
\end{tabular}

Note: $-=$ not calculated

hamatus, the first occurrence of Discoaster coalitus, and the first occurrence of Discoaster kugleri (Tables 4 and 5; also in SblendorioLevy and Howe, Chap. 8; Maniscalco and Brunner, Chap. 10; both this volume). The estimated local ages of microfossil datum levels were used to prepare regression age models (age vs. depth) for Sites 954,955 , and 956.

\section{SITE 954}

The bulk of the sequence at Site 954 consists of nannofossil ooze interlayered with volcaniclastic turbidites (Fig. 1). However, Site 954 is more strongly disrupted by large downslope events (indicated on the right axis of Fig. 1) and poor core recovery than Site 953, because it lies closer to the volcanoes of Gran Canaria. A lapillistone is associated with an interval of poor recovery from 79.2 to $109.7 \mathrm{mbsf}$ and the commencement of rotary drilling. Another lapillistone occurs between 177.34 and 179.18 mbsf and is associated with particularly poor sediment recovery in the overlying interval from 157.9 to 177.2 mbsf. Sediment recovery was only $\sim 30 \%$ in most cores from the base of the lapillistone at 179.18 to $263.7 \mathrm{mbsf}$, but improved in deeper cores (Shipboard Scientific Party, 1995b). About 12 slumps occur between 244.2 and $361.6 \mathrm{mbsf}$ and may be related to volcanic episodes and sediment loading on the island flanks. A massive basalt breccia with hyaloclastic material marks the base of the hole from 407.8 to 446.0 mbsf.

The biostratigraphy at Site 954 compared to that of Site 953 is degraded by large-scale downslope events and poor core recovery, although the microfossils are better preserved throughout most of the sequence (Fig. 5; Maniscalco and Brunner, Chap. 10, this volume; Shipboard Scientific Party, 1995b). A repeat of middle Pleistocene Zone $\mathrm{CN} 14$ between two intervals of Zone $\mathrm{CN} 13$ occurs between 77.32 and the top of the lapillistone at $79.2 \mathrm{mbsf}$; however, there is no clear lithologic evidence of a slump. Poor recovery within the lapillistone from 79.2 to $109.7 \mathrm{mbsf}$ is associated with the loss of most of Zone PL6, which is represented by a single sample at 100.09 mbsf, and the lack of differentiation of Zone CN13 into its upper and lower subzones. In the Pliocene, the very short Zone PL4 (0.03 m.y.) is missing between two samples, which are only one meter apart, but this does not suggest a disconformity. All foraminifer zones are present from PL3 to M11, but poor microfossil preservation made the sequence below $\sim 390$ mbsf assignable only to an undifferentiated Zone M7/10 or older. Nannofossil preservation deteriorated similarly so that samples at various depths had to be assigned to undifferentiated zones (Subzones CN10 b-d, Zone CN8/7, and Zone CN6/7).

Lithostratigraphy indicates a long hiatus at $408 \mathrm{mbsf}$ from $\sim 10.7$ to $\sim 14 \mathrm{Ma}$, suggested by lithostratigraphic Unit III resting directly on 
Table 3. Radiometric ages of samples from Sites 953, 954, 955, and 956.

\begin{tabular}{|c|c|c|c|c|c|}
\hline Radiometric sample & $\begin{array}{l}\text { Depth } \\
\text { (mbsf) }\end{array}$ & $\begin{array}{l}\text { Radiomet. } \\
\text { Age (Ma) }\end{array}$ & $\begin{array}{c}\text { Radiomet. } \\
\text { age error } \\
\text { (m.y.) }\end{array}$ & $\begin{array}{c}\text { Estimated age } \\
\text { (Ma) }\end{array}$ & $\begin{array}{l}\text { Difference } \\
\quad(\mathrm{m} . \mathrm{y} .)\end{array}$ \\
\hline $953 \mathrm{~A}-2 \mathrm{H}-4,77-79 \mathrm{~cm}$, volcaniclastic & 12.87 & 0.246 & 0.009 & 0.37 & 0.12 \\
\hline $953 \mathrm{~A}-2 \mathrm{H}-5,147-150 \mathrm{~cm}$, fallout tephra & 15.08 & 0.273 & 0.006 & 0.40 & 0.13 \\
\hline $953 \mathrm{~A}-5 \mathrm{H}-1,56-57 \mathrm{~cm}$, fallout tephra & 36.66 & 0.61 & 0.02 & 0.69 & 0.08 \\
\hline $953 \mathrm{~A}-14 \mathrm{H}-1,83-84 \mathrm{~cm}$, fallout tephra & 122.43 & 1.83 & 0.02 & 1.84 & 0.01 \\
\hline $953 \mathrm{X}$ syn-ignimbrite, top & 814.54 & 13.7 & & 14.08 & 0.38 \\
\hline 953 X syn-ignimbrite, bottom & 814.65 & 13.7 & & 14.08 & 0.38 \\
\hline 953 D syn-ignimbrite, top & 784.76 & 13.44 & & 13.75 & 0.31 \\
\hline 953 D syn-ignimbrite, bottom & 786.15 & 13.44 & & 13.77 & 0.33 \\
\hline 953 P1 syn-ignimbrite, top & 843.15 & 13.95 & & 14.40 & 0.45 \\
\hline 953 P1 syn-ignimbrite, bottom & 844.03 & 13.95 & & 14.41 & 0.46 \\
\hline 954A-4H-6, 58-64 cm, volcaniclastic & 28.08 & 2.13 & 0.07 & 0.49 & -1.64 turb. \\
\hline $954 \mathrm{~A}-7 \mathrm{H}-5,94-100 \mathrm{~cm}$, volcaniclastic & 55.44 & 0.89 & 0.02 & 0.81 & -0.08 \\
\hline $954 \mathrm{~A}-8 \mathrm{H}-3,81-86 \mathrm{~cm}$, volcaniclastic & 61.81 & 0.86 & 0.01 & 0.89 & 0.03 \\
\hline $954 \mathrm{~A}-9 \mathrm{H}-4,26-31 \mathrm{~cm}$, volcaniclastic & 72.26 & 1.15 & 0.04 & 1.01 & -0.14 \\
\hline $954 \mathrm{~B}-1 \mathrm{R}-1,64-72 \mathrm{~cm}$, volcaniclastic & 80.84 & 1.46 & 0.04 & Lapillistone & - \\
\hline $954 \mathrm{~B}-4 \mathrm{R}-2,37-51 \mathrm{~cm}$, fallout tephra & 111.61 & 2.37 & 0.02 & 2.47 & 0.10 \\
\hline 954B-5R-3, 71-73 cm, fallout tephra & 123.01 & 2.74 & 0.01 & 2.68 & -0.06 \\
\hline $955 X$ syn-ignimbrite, top & 548.32 & 13.7 & & No estimate & - \\
\hline $955 X$ syn-ignimbrite, bottom & 548.38 & 13.7 & & No estimate & - \\
\hline 955 P1 syn-ignimbrite, top & 565.24 & 13.95 & & No estimate & - \\
\hline 955 P1 syn-ignimbrite, bottom & 567.19 & 13.95 & & No estimate & - \\
\hline 956A-3H-2, 81-87 cm, volcaniclastic & 17.94 & 0.244 & 0.006 & No estimate & - \\
\hline $956 \mathrm{~A}-6 \mathrm{H}-1,5-12 \mathrm{~cm}$, volcaniclastic & 44.15 & 1.68 & 0.02 & 1.61 & -0.07 \\
\hline 956A-6H-2, 120-122 cm, volcaniclastic & 46.80 & 1.67 & 0.02 & 1.67 & 0.00 \\
\hline $956 \mathrm{~A}-6 \mathrm{H}-2,124-126 \mathrm{~cm}$, volcaniclastic & 46.84 & 1.70 & 0.01 & 1.67 & -0.03 \\
\hline $956 \mathrm{~A}-7 \mathrm{H}-5,107-109 \mathrm{~cm}$, volcaniclastic & 60.67 & 2.00 & 0.05 & 1.97 & -0.03 \\
\hline $956 \mathrm{~A}-7 \mathrm{H}-6,108-122 \mathrm{~cm}$, volcaniclastic & 62.18 & 2.04 & 0.02 & 2.01 & -0.03 \\
\hline $956 \mathrm{~A}-8 \mathrm{H}-3,14-19 \mathrm{~cm}$, volcaniclastic & 66.24 & 2.04 & 0.02 & 2.10 & 0.06 \\
\hline $956 \mathrm{~A}-8 \mathrm{H}-6,20-26 \mathrm{~cm}$, volcaniclastic & 70.80 & 2.13 & 0.02 & 2.20 & 0.07 \\
\hline $956 \mathrm{~A}-9 \mathrm{H}-1,33-34 \mathrm{~cm}$, volcaniclastic & 72.93 & 2.24 & 0.02 & 2.25 & 0.01 \\
\hline $956 \mathrm{~A}-9 \mathrm{H}-2,36-42 \mathrm{~cm}$, volcaniclastic & 74.46 & 2.19 & 0.02 & 2.28 & 0.09 \\
\hline $956 \mathrm{~A}-11 \mathrm{H}-2,68-70 \mathrm{~cm}$, fallout tephra & 93.78 & 2.47 & 0.02 & 2.69 & 0.22 \\
\hline 956 P1 syn-ignimbrite top & 563.73 & 13.95 & & No estimate & - \\
\hline 956 P1 syn-ignimbrite bottom & 564.19 & 13.95 & & No estimate & - \\
\hline
\end{tabular}

Notes: Ages from Bogaard and Schmincke (Chap. 11, this volume), Sumita and Schmincke (Chap. 15, this volume), Bogaard (Chap. 19, this volume), and Shipboard Scientific Party (1995a through 1995d). Estimated ages are calculated from the age models of this paper (see Table 5). Difference $=$ estimated age/radiometric age, and $-=$ not calculated.

a unit equivalent to lithostratigraphic Unit VI at Site 953. Most of the marine equivalents of the Fataga and all of the Mogan eruptive stages are missing. The biostratigraphy is consistent with this interpretation, but did not refine the interpretation (Fig. 5). Both the nannofossil and foraminifer zonations show repeated zones in the nannofossil chalk at 407 mbsf just above the basalt breccia, suggesting a possible slump of older material (Zones CN6 and CN5) between 398.07 and 405.71 mbsf or older microfossils reworked by turbidites. The oldest inplace sediment is probably that at 407 mbsf (Shipboard Scientific Party, 1995b) just above the basalt breccia, and it belongs to the undifferentiated Zones CN6/7 (9.4 to $11.3 \mathrm{Ma}$ ), which is consistent with the proposed termination of the hiatus based on lithostratigraphy. Well-preserved planktonic foraminifers were noticed in thin sections from the matrix of the basalt breccia, but they were not identified with confidence, although tentatively they were considered no older than 12.7 to $14.8 \mathrm{Ma}$ (Zone M7; Shipboard Scientific Party, 1995b).

Magnetostratigraphy is highly discontinuous at Site 954 (Shipboard Scientific Party, 1995b). The Brunhes/Matuyama boundary was identified at 50.5 to $51 \mathrm{mbsf}$, but no subchrons could be identified in the remainder of the upper Matuyama sequence, perhaps because the magnetic signal was disrupted by the coarse turbidites and possible slump above the lapillistone at 80 to $90 \mathrm{mbsf}$. Within the rotary drilled sequence of Hole 954B, several intervals of the polarity record were placed in magnetostratigraphic context with the aid of paleontologic datum levels, specifically, the top of the Gauss Chron, then two adjacent subchrons from the base of C3An.2n to the base of $\mathrm{C} 3 \mathrm{Bn}$, and three adjacent subchrons from the top of $\mathrm{C} 4 \mathrm{n} .2 \mathrm{n}$ to the top of C4An. No other chrons or subchrons were recognized.

An age model was constructed for Site 954, using microfossil datum levels with local ages estimated from Site 953 (Fig. 6) and the limited magnetostratigraphy outlined above. Datum levels were well described by four line segments (see standard errors of the age esti- mates, Table 2), except for two problem areas where datum levels fell at some distance from the model line. The first problem lies at the base of the sequence, where there is great scatter among the datum levels. Two datum levels are shallower (younger) than expected, the local first occurrences of $G$. nepenthes and $N$. acostaensis, perhaps because dissolution removed the first specimens from the middle Miocene portion of the sequence. The sequence is also disturbed by a slump, so the interval was not modeled. The second problem area occurred between 175 and 250 mbsf, where datum levels are more distant from the model line than in other parts of the sequence. The last occurrences of Globorotalia margaritae and Amaurolithus spp. are deeper (older) than expected in the hole, increasing the uncertainty (error) of the model line.

The model lines are offset at two points, suggesting hiatuses (Fig. 6). The first offset occurs in the slump and lapillistone between 77.32 and $109.7 \mathrm{mbsf}$, and spans $1.36 \mathrm{~m}$.y. from 1.07 to $2.43 \mathrm{Ma}$, according to extrapolation of the regression lines to the top of the slump and the base of the lapillistone. This is supported by the age of the first occurrence of Reticulofenestra asanoi at $78.62 \mathrm{mbsf}$ of 1.23-1.25 Ma and the last occurrence of Discoaster surculus at 112.25 mbsf of 2.552.59 Ma for a minimum duration of $1.3 \mathrm{~m}$.y. The second offset occurs at $377 \mathrm{mbsf}$ and involves $0.99 \mathrm{~m} . \mathrm{y}$. between 8.76 and $9.75 \mathrm{Ma}$ at the younger peak in Fataga volcanic production, based on extrapolation of the regression lines to the depth of the hiatus. The hiatus is supported by the last occurrence of common Reticulofenestra pseudoumbilicus $(>7 \mu \mathrm{m})$ at $377.83 \mathrm{mbsf}$, dated at $8.70-8.80 \mathrm{Ma}$ and the first occurrence of $M$. convallis at 379.83 , dated at 9.70-9.80 Ma for a minimum duration of $1 \mathrm{~m} . \mathrm{y}$. The top of Hole 954A appears to be missing the first $0.16 \mathrm{~m} . \mathrm{y}$. of deposition, based on extrapolation of the regression line from the upper Quaternary datum levels.

Radiometric dates from single crystal laser ${ }^{40} \mathrm{Ar} /{ }^{39} \mathrm{Ar}$ analyses were restricted to the Quaternary and the late Pliocene (Bogaard, 


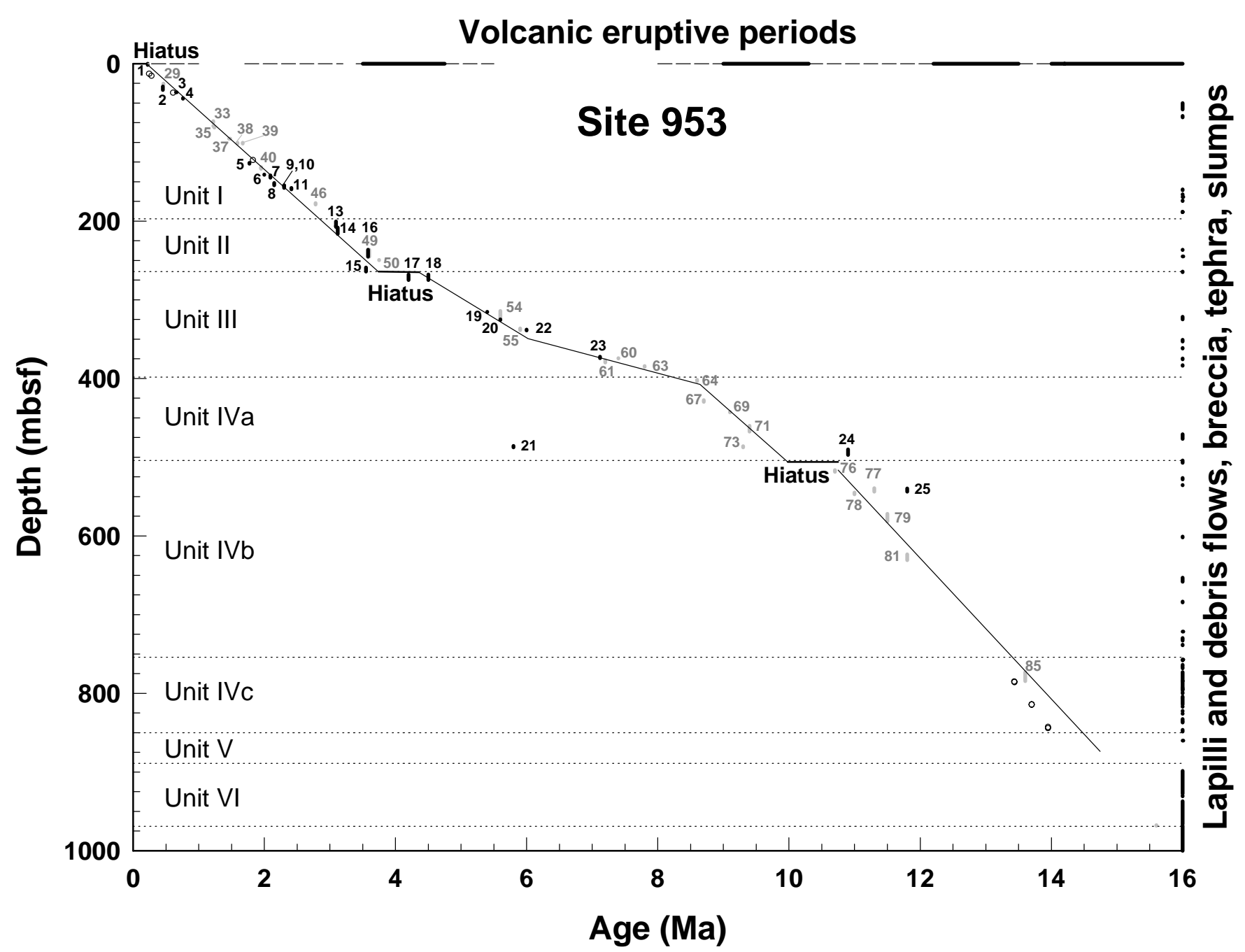

Figure 4. Estimation of local ages of biostratigraphic datum levels using the regression model of Site 953. First and last occurrences of planktonic foraminifers and calcareous nannofossils are plotted using the global or oceanwide age estimates from Berggren et al. (1995a, 1995b). The local ages of first and last occurrences are estimated using the regression model lines and are graphically equivalent to projecting the datum levels horizontally onto the model lines and reading the age of the projected point from the age axis. Each first and last occurrence is marked by a line indicating the stratigraphic error, the interval between the depth of the microfossil event, and the depth of the adjacent sample where it is absent. The datum levels are coded by numbers that correspond to Tables 4 and 5. The timing of volcanic eruptive periods on Gran Canaria is plotted on the secondary age axis, and the depths of lapillistones, debris flows, breccia, slumps and other coarse-grained deposits are plotted on the secondary depth axis. The boundaries of the lithostratigraphic units are marked as dashed horizontal dashed lines.

Chap. 19, this volume), and, in general, confirm the biostratigraphic age model (Fig. 6; Table 3). Three of four dates fall close (within twice the standard error of the age estimate) to the model line for the Quaternary, and the fourth date is anomalously old and included feldspar crystals reworked from Fataga syn-ignimbrite turbidites (Bogaard, Chap. 19, this volume; Schmincke, pers. comm., 1997; Sample 157-954-4H-6, 58-64 cm). Two samples from the Pliocene also lie within the standard deviation of the model line. A further radiometric test was possible. The dated samples bracket the disconformity: one closely overlies the slumped interval and is $1.15 \mathrm{Ma}$; a second dated sample places the volcanic debris at the top of the lapillistone at $1.43 \mathrm{Ma}$; and a coarse ash layer beneath the base of the slump (111.61 mbsf) is $2.47 \mathrm{Ma}$. The radiometric ages above and below the lapillistone are (within the standard errors of the age estimates) very close to the model estimates of 1.07-2.43 Ma (Fig. 6; Table 3).

Sedimentation rate changes are nearly age equivalent at Sites 954 and 953, but in the opposite sense in magnitude (Table 2). The rates decrease from a range of $40-46 \mathrm{~m} / \mathrm{m}$.y. from 8.8 to 6.3 Ma during the early major nonvolcanic phase to $16-31 \mathrm{~m} / \mathrm{m}$.y. from 6.3 to $4.9 \mathrm{Ma}$ during the late major nonvolcanic phase. Rates increase to $49-61 \mathrm{~m} /$ m.y. during the Roque Nublo events, and increase further to 67-114 $\mathrm{m} / \mathrm{m}$.y. during the Quaternary (Table 5). Sedimentation rates were estimated from the regression equations at $95 \%$ confidence intervals. Wider ranges in rates suggest greater stratigraphic uncertainty.

\section{SITE 955}

The sections cored at Sites 955 and 956 differ in two principal respects from those on the north side of Gran Canaria. The southern sites receive turbidites from the continental margin of Africa, whereas the northern sites are isolated from such input by volcanic ridges and sills. The southern sites are more strongly affected by slumping than the northern sites, so much so that biostratigraphic zones are frequently repeated, and modeling of sediment accumulation is complicated.

Slumped intervals at Site 955 comprise a minimum of $8 \%$ of the recovered sequences, and particularly affect the upper $177 \mathrm{mbsf}$ of 
Table 4. Planktonic foraminifer first and last occurrences at Sites 953, 954, 955, and 956.

\begin{tabular}{|c|c|c|c|c|c|c|c|}
\hline & Code & $\begin{array}{l}\text { Age } \\
\text { (Ma) }\end{array}$ & $\begin{array}{c}\text { Estimated } \\
\text { age (Ma) }\end{array}$ & $\begin{array}{c}953 \\
\text { Depth } \\
\text { (mbsf) }\end{array}$ & $\begin{array}{c}954 \\
\text { Depth } \\
\text { (mbsf) }\end{array}$ & $\begin{array}{c}955 \\
\text { Depth } \\
\text { (mbsf) }\end{array}$ & $\begin{array}{c}956 \\
\text { Depth } \\
\text { (mbsf) }\end{array}$ \\
\hline FO Gg. calida calida & 1 & 0.22 & $\begin{array}{l}0.20 \\
0.22\end{array}$ & $\begin{array}{l}0.00 \\
1.30\end{array}$ & $\begin{array}{l}11.21 \\
12.11\end{array}$ & $\begin{array}{r}7.90 \\
17.67\end{array}$ & \\
\hline FO Gr. hirsuta tropical form & 2 & 0.45 & $\begin{array}{l}0.22 \\
0.59 \\
0.65\end{array}$ & $\begin{array}{l}28.96 \\
3348\end{array}$ & 25.11 & & \\
\hline LO Gr. tosaensis & 3 & 0.65 & $\begin{array}{l}0.69 \\
0.69\end{array}$ & $\begin{array}{l}36.10 \\
36.21\end{array}$ & $\begin{array}{l}40.97 \\
45.91\end{array}$ & & \\
\hline FO pink Gn. ruber & 4 & 0.76 & $\begin{array}{l}0.79 \\
0.80\end{array}$ & $\begin{array}{l}43.71 \\
44.35\end{array}$ & & & \\
\hline LO Gn. extremus & 5 & 1.77 & $\begin{array}{l}1.89 \\
1.90\end{array}$ & $\begin{array}{l}125.94 \\
127.12\end{array}$ & $\begin{array}{r}79.20 \\
100.09\end{array}$ & $\begin{array}{l}112.67 \\
122.29\end{array}$ & \\
\hline FO of common Gr. truncatulinoides & 6 & 2.00 & $\begin{array}{l}2.08 \\
2.09\end{array}$ & $\begin{array}{l}140.56 \\
140.95\end{array}$ & $\begin{array}{r}79.20 \\
100.09\end{array}$ & $\begin{array}{l}101.50 \\
103.08\end{array}$ & $\begin{array}{l}60.10 \\
63.15\end{array}$ \\
\hline FO Gr. inflata & 7 & 2.09 & $\begin{array}{l}2.10 \\
2.14\end{array}$ & $\begin{array}{l}141.71 \\
144.76\end{array}$ & $\begin{array}{r}79.20 \\
100.09\end{array}$ & $\begin{array}{l}101.50 \\
103.08\end{array}$ & $\begin{array}{l}72.10 \\
82.15\end{array}$ \\
\hline LO Gr. exilis & 8 & 2.15 & $\begin{array}{l}2.23 \\
2.27\end{array}$ & $\begin{array}{l}151.65 \\
154.49\end{array}$ & $\begin{array}{r}79.20 \\
100.09\end{array}$ & $\begin{array}{l}112.67 \\
122.29\end{array}$ & $\begin{array}{l}72.10 \\
82.14\end{array}$ \\
\hline LO Gr. miocenica & 9 & 2.30 & $\begin{array}{l}2.27 \\
2.31\end{array}$ & $\begin{array}{l}154.71 \\
157.79\end{array}$ & $\begin{array}{l}100.09 \\
110.59\end{array}$ & $\begin{array}{l}103.07 \\
112.66\end{array}$ & $\begin{array}{l}72.10 \\
82.14\end{array}$ \\
\hline Reoccurrence of Pulleniatina & 10 & 2.30 & $\begin{array}{l}2.27 \\
2.27\end{array}$ & $\begin{array}{l}154.49 \\
154.71\end{array}$ & & $\begin{array}{r}79.20 \\
100.09\end{array}$ & $\begin{array}{l}63.16 \\
72.10\end{array}$ \\
\hline LO Gr. puncticulata & 11 & 2.41 & $\begin{array}{l}2.31 \\
2.34\end{array}$ & $\begin{array}{l}157.79 \\
159.61\end{array}$ & $\begin{array}{r}79.20 \\
100.09\end{array}$ & $\begin{array}{l}103.10 \\
112.68\end{array}$ & $\begin{array}{l}82.15 \\
91.10\end{array}$ \\
\hline LO D. altispira & 12 & 3.09 & $\begin{array}{l}2.97 \\
2.98\end{array}$ & $\begin{array}{l}206.47 \\
207.41\end{array}$ & $\begin{array}{l}141.99 \\
143.56\end{array}$ & $\begin{array}{l}112.97 \\
122.29\end{array}$ & $\begin{array}{r}91.10 \\
101.35\end{array}$ \\
\hline LO Gr: multicamerata & 13 & 3.09 & $\begin{array}{l}2.88 \\
2.97\end{array}$ & $\begin{array}{l}200.25 \\
206.47\end{array}$ & $\begin{array}{l}140.93 \\
142.00\end{array}$ & $\begin{array}{l}112.97 \\
122.29\end{array}$ & $\begin{array}{r}91.10 \\
101.35\end{array}$ \\
\hline LO Ss. seminulina & 14 & 3.12 & $\begin{array}{l}2.99 \\
3.10\end{array}$ & $\begin{array}{l}207.96 \\
216.28\end{array}$ & $\begin{array}{l}141.99 \\
143.56\end{array}$ & $\begin{array}{l}131.81 \\
141.23\end{array}$ & $\begin{array}{l}158.09 \\
159.54\end{array}$ \\
\hline FO Gr. miocenica & 15 & 3.55 & $\begin{array}{l}4.24 \\
4.35\end{array}$ & $\begin{array}{l}258.89 \\
264.49\end{array}$ & $\begin{array}{l}198.48 \\
199.23\end{array}$ & $\begin{array}{l}178.26 \\
184.48\end{array}$ & $\begin{array}{l}158.10 \\
159.54\end{array}$ \\
\hline LO Gr. margaritae & 16 & 3.58 & $\begin{array}{l}3.36 \\
3.48\end{array}$ & $\begin{array}{l}236.24 \\
245.10\end{array}$ & $\begin{array}{l}188.08 \\
190.17\end{array}$ & $\begin{array}{l}189.00 \\
203.57\end{array}$ & $\begin{array}{l}148.76 \\
157.59\end{array}$ \\
\hline LO Gg. nepenthes & 17 & 4.2 & $\begin{array}{l}4.41 \\
4.55\end{array}$ & $\begin{array}{l}267.80 \\
274.61\end{array}$ & $\begin{array}{l}206.19 \\
216.06\end{array}$ & $\begin{array}{l}233.84 \\
243.58\end{array}$ & $\begin{array}{l}203.76 \\
213.22\end{array}$ \\
\hline FO Gr. puncticulata & 18 & 4.5 & $\begin{array}{l}4.41 \\
4.55\end{array}$ & $\begin{array}{l}267.80 \\
274.61\end{array}$ & $\begin{array}{l}206.19 \\
216.05\end{array}$ & $\begin{array}{l}209.13 \\
221.00\end{array}$ & $\begin{array}{l}203.76 \\
213.22\end{array}$ \\
\hline LO Gr. juanai & 19 & 5.4 & $\begin{array}{l}5.35 \\
5.36\end{array}$ & $\begin{array}{l}315.25 \\
315.51\end{array}$ & $\begin{array}{l}254.58 \\
255.38\end{array}$ & $\begin{array}{l}262.87 \\
272.57\end{array}$ & $\begin{array}{l}256.59 \\
258.42\end{array}$ \\
\hline FO Gr. tumida & 20 & 5.6 & $\begin{array}{l}5.55 \\
5.56\end{array}$ & $\begin{array}{l}325.00 \\
325.57\end{array}$ & $\begin{array}{l}262.87 \\
272.57\end{array}$ & $\begin{array}{l}220.70 \\
250.98\end{array}$ & \\
\hline LO Gq. dehiscens & 21 & 5.8 & $\begin{array}{l}9.70 \\
9.73\end{array}$ & $\begin{array}{l}485.50 \\
487.44\end{array}$ & $\begin{array}{l}386.69 \\
388.36\end{array}$ & $\begin{array}{l}358.51 \\
368.06\end{array}$ & $\begin{array}{l}399.17 \\
413.21\end{array}$ \\
\hline FO Gr. margaritae & 22 & 6.0 & $\begin{array}{l}5.79 \\
5.82\end{array}$ & $\begin{array}{l}337.59 \\
338.76\end{array}$ & $\begin{array}{l}264.63 \\
267.07\end{array}$ & $\begin{array}{l}262.86 \\
272.56\end{array}$ & $\begin{array}{l}269.46 \\
275.85\end{array}$ \\
\hline FO Gr. conomiozea & 23 & 7.12 & $\begin{array}{l}7.05 \\
7.14\end{array}$ & $\begin{array}{l}372.02 \\
373.91\end{array}$ & $\begin{array}{l}304.00 \\
313.46\end{array}$ & $\begin{array}{l}348.83 \\
358.51\end{array}$ & $\begin{array}{l}376.26 \\
386.14\end{array}$ \\
\hline FO Nq. acostaensis & 24 & 10.9 & $\begin{array}{l}9.76 \\
9.86\end{array}$ & $\begin{array}{l}489.99 \\
497.03\end{array}$ & $\begin{array}{l}376.51 \\
377.53\end{array}$ & $\begin{array}{l}422.29 \\
433.69\end{array}$ & $\begin{array}{l}445.35 \\
458.74\end{array}$ \\
\hline FO Gg. nepenthes & 25 & 11.8 & $\begin{array}{l}11.01 \\
11.06\end{array}$ & $\begin{array}{l}539.47 \\
543.77\end{array}$ & $\begin{array}{l}386.69 \\
388.36\end{array}$ & $\begin{array}{l}433.69 \\
444.79\end{array}$ & $\begin{array}{l}445.35 \\
458.74\end{array}$ \\
\hline LO Gr peripheroronda & 26 & 14.6 & $\begin{array}{l}14.6 \\
14.6\end{array}$ & $\begin{array}{l}517.74 \\
527.31\end{array}$ & $\begin{array}{l}505.88 \\
513.81\end{array}$ & & \\
\hline FO Orbulina spp. & 27 & 15.1 & $\begin{array}{l}15.1 \\
15.1\end{array}$ & $\begin{array}{l}499.00 \\
517.73\end{array}$ & $\begin{array}{l}513.81 \\
524.75\end{array}$ & & \\
\hline
\end{tabular}

Notes: Age $=$ ages of datum levels from Berggren et al. $(1995 \mathrm{a}, \mathrm{b})$. Estimated age = ages calculated from the regression age model of Site 953 (see Table 5), FO = deepest (first) stratigraphic occurrence of a taxon, and $\mathrm{LO}=$ shallowest (last) stratigraphic occurrence of a taxon.

nannofossil mixed sediments (Fig. 7; Goldstrand, Chap. 20, this volume). Recognition of slump structures below $177 \mathrm{mbsf}$, however, is difficult because of disturbance by extended core barrel coring from 175 to 207 mbsf and disruption from degassing between 207 and 273 mbsf. Identification of sedimentary structures is also difficult because of biscuiting below 474 mbsf. Despite the recovery problems, slumping seems to diminish with depth at the site. In general, the coarse volcaniclastics that are so prominent in various intervals of Sites 953 and 954 are less important at this locale. Pumice lapilli and other coarse but thin volcaniclastic tuffs appear between 513 and 567 mbsf, but tuffs are absent below 567 mbsf, where nannofossil mixed sediment with quartz-rich sandy turbidites are as important as they are above the tuff-rich interval.

Biostratigraphy revealed several hiatuses and slumps in the sequence at Site 955 (Fig. 5). Calcareous nannofossil Subzone CN13a is missing between 102.81 and $103.08 \mathrm{mbsf}$ at the base of a slump detected by sedimentary structures, and planktonic foraminifer zones are shortened or missing in the same interval and between 112 and $122 \mathrm{mbsf}$ at the base of another slump detected by sedimentary structures (lower Subzone PT1a, Zone PL6, and upper Zone PL5). Sub- zones $\mathrm{CN} 12 \mathrm{~b}$ and $\mathrm{CN} 12 \mathrm{c}$ may be missing between 114.86 and 122.19 mbsf, where slump structures were described at 122.3 to 122.5 mbsf (Goldstrand, Chap. 20, this volume). A slump is inferred between 131.81 and 141.90 mbsf based on the occurrence of Zone CN10 amid younger Subzone CN12a. The corresponding, older foraminifer zone occurs here also, Zone PL1, and small slumps are described, based on sedimentary structures from 130.2 to $130.21 \mathrm{mbsf}$, 131.8 to 131.81 mbsf, 131.8 to 132 mbsf, 141.2 to $141.4 \mathrm{mbsf}$, and 141.9 to 141.91 (Goldstrand, Chap. 20, this volume).

There is biostratigraphic evidence for disconformities in the lower Pliocene and Miocene intervals based on missing subzones and truncated species ranges (Fig. 5). Subzone $\mathrm{CN} 11 \mathrm{~b}$ is missing or abbreviated between 203.11 and 208.99 mbsf, and Zone M13 is missing or abbreviated between Zones PL1 at 262.87 and M12 at 272.57 mbsf. An erosion event in the late Miocene is indicated by the truncated first occurrence of M. convallis ( $9.7 \mathrm{Ma}$ at $364 \mathrm{mbsf}$ ), the absence of Subzone CN8a between 364.00 and $373.60 \mathrm{mbsf}$, and the simultaneous last occurrences of D. hamatus and $R$. pseudoumbilicus $(>7 \mu \mathrm{m})$ between 8.7-8.8 and 9.4-9.5 Ma at $373.60 \mathrm{mbsf}$. The erosion removed sediment spanning at least 0.7 m.y. 
Table 5. Calcareous nannofossil first and last occurrences at Sites 953, 954, 955, and 956.

\begin{tabular}{|c|c|c|c|c|c|c|c|}
\hline Calcareous nannofossil event & Code & $\begin{array}{l}\text { Age } \\
(\mathrm{Ma})\end{array}$ & $\begin{array}{c}\text { Estimated } \\
\text { age (Ma) }\end{array}$ & $\begin{array}{c}\text { Site } 953 \\
\text { depth } \\
(\mathrm{mbsf})\end{array}$ & $\begin{array}{c}\text { Site } 954 \\
\text { depth } \\
(\mathrm{mbsf})\end{array}$ & $\begin{array}{l}\text { Site } 955 \\
\text { depth } \\
(\mathrm{mbsf})\end{array}$ & $\begin{array}{c}\text { Site } 956 \\
\text { depth } \\
(\mathrm{mbsf})\end{array}$ \\
\hline \multirow[t]{2}{*}{ LO Pseudoemiliania lacunosa } & 29 & 0.46 & 0.43 & 25.02 & 25.1 & 27.3 & 6.06 \\
\hline & & 0.46 & 0.46 & 26.58 & 29.08 & 29.3 & 22.18 \\
\hline \multirow[t]{2}{*}{ LO Reticulofenestra asanoi } & 30 & & 0.83 & 46.32 & 62.2 & 55.16 & \\
\hline & & & 0.85 & 47.70 & 62.85 & 56.28 & \\
\hline \multirow[t]{2}{*}{ FO common Reticulofenestra asanoi } & 31 & & 1.03 & 61.21 & & & \\
\hline & & & 1.05 & 62.70 & & & \\
\hline \multirow[t]{2}{*}{ FO Gephyrocapsa omega/parallela } & 32 & & 1.08 & 64.73 & & & \\
\hline & 33 & 1.22 & $\begin{array}{l}1.08 \\
1.19\end{array}$ & $\begin{array}{l}65.02 \\
72.90\end{array}$ & & & \\
\hline LO Helicosphaera sellii & & 1.22 & 1.21 & 74.49 & & & \\
\hline FO Reticulofenestra asanoi & 34 & & 1.23 & 75.70 & 78.62 & 73.33 & \\
\hline & & & 1.25 & 77.40 & 79.34 & 74.92 & \\
\hline LO large Gephyrocapsa $(>5.5 \mu \mathrm{m})$ abundance & 35 & 1.22 & 1.27 & 78.96 & & 74.92 & \\
\hline interval & & 1.24 & 1.30 & 80.98 & & 82.54 & \\
\hline FO large Gephyrocapsa $(>5.5 \mu \mathrm{m})$ & 37 & 1.46 & 1.49 & 95.29 & & 93.23 & \\
\hline & & 1.48 & 1.52 & 95.30 & & 93.93 & \\
\hline LO Calcidiscus macintyrei & 38 & 1.59 & 1.56 & 100.37 & 79.34 & & 33.26 \\
\hline & & 1.59 & 1.57 & 101.33 & 81.42 & & 44.25 \\
\hline FO medium Gephyrocapsa $(4.0 \mu \mathrm{m})$ & 39 & 1.67 & 1.56 & 100.37 & & & \\
\hline & & 1.7 & 1.57 & 101.33 & & & \\
\hline LO Discoaster brouweri & 40 & 1.95 & 1.91 & 131.61 & 81.42 & 102.08 & 50.43 \\
\hline & & 1.95 & 1.93 & 133.34 & 100.1 & 103.08 & 60.12 \\
\hline LO Discoaster triradiatus & 41 & 2.18 & 1.91 & 131.61 & & & \\
\hline & & 2.18 & 1.93 & 133.34 & & & \\
\hline LO Discoaster pentaradiatus & 42 & 2.46 & Deb. flow & 158.03 & 100.1 & & 75.86 \\
\hline & & 2.56 & & 159.61 & 110.39 & & 82.15 \\
\hline LO Discoaster surculus & 43 & 2.55 & Deb. flow & 159.61 & 110.39 & & 82.15 \\
\hline FO Gephyrocapsa spp. small (<4.0 um) & 44 & 2.59 & 251 & $\begin{array}{l}160.83 \\
16270\end{array}$ & 112.25 & & 84.63 \\
\hline 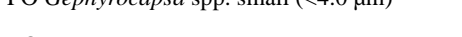 & $4+4$ & & 2.58 & 167.89 & & & \\
\hline LO Discoaster asymmetricus & 45 & & 2.51 & 162.70 & & & \\
\hline & & & 2.58 & 167.89 & & & \\
\hline LO Discoaster tamalis & 46 & 2.78 & 2.71 & 176.84 & 112.68 & 114.86 & \\
\hline LO Sphenolithus spp. & 47 & 3.6 & $\begin{array}{l}2.13 \\
3.54\end{array}$ & $\begin{array}{l}178.70 \\
236.23\end{array}$ & 121.09 & & \\
\hline & & 3.6 & 3.66 & 245.11 & & & \\
\hline LO “mid-Pliocene" small Gephyrocapsa spp. & 48 & & 3.69 & 246.95 & & & \\
\hline$(<4.0 \mu \mathrm{m})$ interval & & & 3.71 & 248.55 & & & \\
\hline LO Reticulofenestra pseudoumbilica $(>7 \mu \mathrm{m})$ & 50 & 3.75 & 3.72 & 249.27 & 187.8 & & \\
\hline FO common Discoaster tamalis & 51 & 3.75 & $\begin{array}{l}3.72 \\
4.02\end{array}$ & $\begin{array}{l}249.40 \\
258.67\end{array}$ & $\begin{array}{l}190.18 \\
197.21\end{array}$ & 203.11 & 159.82 \\
\hline & & & 4.17 & 265.00 & 206.26 & 208.99 & 167.42 \\
\hline FO “mid-Pliocene" small Gephyrocapsa spp. & 52 & & 4.02 & 258.67 & & & \\
\hline$(<4.0 \mu \mathrm{m})$ interval & & & 4.17 & 265.00 & & & \\
\hline LO Amaurolithus spp. & 53 & & 4.22 & 266.83 & 227.1 & 235.9 & 211.25 \\
\hline & & & 4.24 & 267.70 & 234.96 & 248.36 & 219.7 \\
\hline LO Discoaster quinqueramus & 54 & 5.6 & 5.4 & 313.98 & 247.4 & 259.64 & 250.98 \\
\hline & & 5.6 & 5.6 & 324.42 & 254.14 & 262.87 & 256.61 \\
\hline LO Amaurolithus amplificus & 55 & 5.9 & 5.9 & 336.33 & 256.09 & & \\
\hline & & 5.9 & 5.9 & 338.54 & 264.65 & & \\
\hline FO Amaurolithus amplificus & 56 & 6.6 & Slump & 350.68 & 287.92 & & \\
\hline & & 6.6 & & 351.63 & 293.52 & & \\
\hline LO Amaurolithus primus & 57 & 7.2 & Slump & 350.68 & & & \\
\hline & & 7.2 & & 351.63 & & & \\
\hline LO Coccolithus pliopelagicus & 58 & & Slump & $\begin{array}{l}350.68 \\
351.63\end{array}$ & & & \\
\hline FO Amaurolithus delicatus & 59 & & 7.1 & 373.90 & & & \\
\hline & & & 7.1 & 374.35 & & & \\
\hline LO Discoaster loeblichii & 60 & 7.4 & 7.1 & 373.90 & & & \\
\hline & & 7.4 & 7.1 & 374.35 & & & \\
\hline FO Amaurolithus primus & 61 & & 7.2 & 376.51 & 312.18 & 310.78 & 354.31 \\
\hline & & & 7.4 & 379.73 & 322.18 & 317.60 & 362.6 \\
\hline LO Calcidiscus tropicus & 62 & & 7.2 & 376.51 & & & \\
\hline & & & 7.4 & 379.73 & & & \\
\hline LO Minylitha convallis & 63 & 7.8 & 7.7 & 384.00 & & & \\
\hline & & 7.8 & 7.8 & 385.28 & & & \\
\hline FO Discoaster berggrenii & 64 & 8.6 & 8.3 & 401.38 & 355.35 & 340.40 & \\
\hline & & 8.6 & 8.3 & 403.20 & 361.57 & 344.90 & \\
\hline LO common Reticulofenestra spp. & 65 & & 8.7 & 419.08 & & 364 & \\
\hline$(>7,5-7 \mu \mathrm{m}, 3-5 \mu \mathrm{m})$ & & & 8.8 & 422.87 & & 373.6 & \\
\hline FO "large" Reticulofenestra & 66 & & 8.7 & 419.08 & & & \\
\hline absence interval & & & 8.8 & 422.87 & & & \\
\hline FO Discoaster loeblichii & 67 & 8.7 & 8.8 & 427.34 & & & \\
\hline & & 8.7 & 8.9 & 429.45 & & & \\
\hline LO Discoaster neohamatus & 68 & & 9.2 & 439.82 & & & \\
\hline & & & 9.2 & 442.23 & & & \\
\hline LO Discoaster bollii & 69 & 9.1 & 9.2 & 442.21 & & & \\
\hline & & 9.1 & 9.2 & 443.00 & & & \\
\hline FO Discoaster pentaradiatus & 70 & & 9.3 & 457.70 & & & \\
\hline & & & 9.4 & 459.88 & & & \\
\hline LO Discoaster hamatus & 71 & 9.4 & 9.4 & 459.87 & 379.83 & 364 & 399.07 \\
\hline & & 9.4 & 9.5 & 467.26 & 384.26 & 373.60 & 413.3 \\
\hline LO Catinaster coalitus & 72 & & 9.7 & 480.21 & & & \\
\hline & & & 9.8 & 485.69 & & & \\
\hline
\end{tabular}


Table 5 (continued).

\begin{tabular}{|c|c|c|c|c|c|c|c|}
\hline Calcareous nannofossil event & Code & $\begin{array}{l}\text { Age } \\
\text { (Ma) }\end{array}$ & $\begin{array}{c}\text { Estimated } \\
\text { age (Ma) }\end{array}$ & $\begin{array}{c}\text { Site } 953 \\
\text { depth } \\
(\mathrm{mbsf})\end{array}$ & $\begin{array}{c}\text { Site } 954 \\
\text { depth } \\
(\mathrm{mbsf})\end{array}$ & $\begin{array}{c}\text { Site } 955 \\
\text { depth } \\
\text { (mbsf) }\end{array}$ & $\begin{array}{c}\text { Site } 956 \\
\text { depth } \\
\text { (mbsf) }\end{array}$ \\
\hline \multirow[t]{2}{*}{ FO Minylitha convallis } & 73 & 9.5 & 9.7 & 485.69 & 379.83 & 310.78 & \\
\hline & & 9.5 & 9.8 & 487.43 & 384.26 & 317.60 & \\
\hline \multirow[t]{2}{*}{ FO Discoaster neohamatus } & 74 & & 9.8 & 488.22 & & & \\
\hline & & & 9.8 & 490.03 & & & \\
\hline \multirow{2}{*}{ FO Discoaster hamatus } & 76 & 10.7 & 10.2 & 516.07 & 388.57 & 415.18 & 436.47 \\
\hline & & 11.2 & 10.2 & 518.50 & 398.07 & 420.08 & 446.3 \\
\hline \multirow[t]{2}{*}{ FO Discoaster coalitus } & 77 & 11.3 & 10.8 & 539.19 & 398.07 & 432.63 & \\
\hline & & 11.3 & 10.9 & 543.76 & 400.22 & 433.70 & \\
\hline \multirow[t]{2}{*}{ LO common Coccolithus miopelagicus } & 78 & 11.0 & 10.9 & 545.12 & & 444.80 & 436.47 \\
\hline & & 11.0 & 10.9 & 547.31 & & 445.84 & 446.3 \\
\hline \multirow[t]{2}{*}{ LO common Discoaster kugleri } & 79 & 11.5 & 11.3 & 571.84 & & 468.54 & \\
\hline & & 11.5 & 11.4 & 581.48 & & 471.57 & \\
\hline \multirow[t]{2}{*}{ LO Cyclicargolithus floridanus } & 80 & & Slumped & 610.10 & & & \\
\hline & & & interval & 611.03 & & & \\
\hline \multirow[t]{2}{*}{ FO Discoaster kugleri } & 81 & 11.8 & 12.1 & 623.35 & & 483.74 & \\
\hline & & 11.8 & 12.1 & 630.68 & & 487.55 & \\
\hline LO Coronocyclus nitescens & 82 & & 12.2 & 646.35 & & & \\
\hline \multirow[t]{2}{*}{ LO Calcidiscus premacintyrei } & 83 & & $\begin{array}{l}12.3 \\
12.3\end{array}$ & $\begin{array}{l}649.02 \\
652.67\end{array}$ & & & \\
\hline & & & 12.4 & 658.99 & & & \\
\hline \multirow{2}{*}{ FO Calcidiscus macintyrei } & 84 & & 12.3 & 652.67 & & & \\
\hline & & & 12.4 & 658.99 & & & \\
\hline \multirow[t]{2}{*}{ LO Sphenolithus heteromorphus } & 85 & 13.6 & 13.5 & 773.11 & & 517.74 & 505.35 \\
\hline & & 13.6 & 13.6 & 784.34 & 13.44 & 526.60 & 513.8 \\
\hline \multirow[t]{2}{*}{ LO Discoaster petaliformis } & 86 & & 13.7 & 797.27 & & & \\
\hline & & & 13.7 & 799.10 & & & \\
\hline FO Dictyococcites productus/antarcticus & 87 & & & $\begin{array}{l}876.56 \\
879.42\end{array}$ & & & \\
\hline \multirow[t]{2}{*}{ LO Helicosphaera ampliaperta } & 88 & 15.6 & & 967.61 & & 594.90 & \\
\hline & & 15.6 & & 968.16 & & 595.06 & \\
\hline
\end{tabular}

Notes: Age $=$ ages of datum levels from Berggren et al. (1995a, 1995b). Estimated age = local ages interpolated from an age vs. depth plot of magnetostratigraphic boundaries and radiometrically dated horizons at Site 953 (Sblendorio-Levy and Howe, Chap. 8, this volume). FO = deepest (first) stratigraphic occurrence of a taxon, and LO = shallowest (last) stratigraphic occurrence of a taxon. Deb. $=$ debris.

The polarity record at Site 955 was confounded by several problems, including severe slumping and magnetization acquired during drilling (Herr et al., Chap. 6, this volume). Although several boundaries were tentatively recognized during preliminary study (Shipboard Scientific Party, 1995c), none of the data was used in this work, although several middle Miocene subchron boundaries are plotted on Figure 8.

An age model was proposed for Site 955, but applied only in a general sense because datum levels were scattered (Fig. 8) and various statistical measures showed that the model regression lines below the Quaternary suffered from more uncertainty and error than those constructed for Sites 953 and 954 (Table 2). The upper Quaternary, however, has a fairly linear array of datum levels and small errors. Three hiatuses were identified at Site 955 at depths where several datum levels clustered, between 93.6 and $122.5 \mathrm{mbsf}, 260$ and 273 mbsf, and 364 and 374 mbsf. Slumps (from 93.6 to 103.4 mbsf, 112.7 to 112.9 mbsf, and 122.3 to $122.5 \mathrm{mbsf}$ ) are associated with the apparent removal of sediment between the last occurrence of Globigerinoides extremus at 1.89-1.90 Ma and the last occurrence of Globorotalia. mulitcamerata at 2.88-2.97 Ma, and further supported by 10 taxa that made their first or last occurrences over $29 \mathrm{~m}$ in $\sim 1$ m.y. of time. A second hiatus of 0.25 m.y., from 5.55-5.56 to 5.79$5.82 \mathrm{Ma}$ between the local first occurrences of Globorotalia tumida and G. margaritae, is suspected at the base of lithostratigraphic Unit II, where three taxa made their first or last occurrences at 262.87 mbsf, and Zone M13 is missing. A hiatus of 0.7 m.y. from 8.7-8.8 to 9.4-9.5 Ma is suspected at $373.60 \mathrm{mbsf}$, based on the simultaneous last occurrences of D. hamatus and R. pseudoumbilicus $(>7 \mu \mathrm{m})$ and missing Subzone CN8a (Shipboard Scientific Party, 1995c).

Other hiatuses may occur in the Pliocene sequence, for example, at $203.57 \mathrm{mbsf}$, where the last occurrence of $G$. margaritae and the first occurrence of common Discoaster tamalis coincide (3.36-3.48 to $4.02-4.17 \mathrm{Ma}, 0.7$ m.y.), and Subzone CN11b is missing from an interval affected by slumping of the African continental margin. A large lower Pliocene slump block lies amid upper Pliocene sediments between 130 and $142 \mathrm{mbsf}$, but no hiatus was discerned in association with it.

No radiometric dates are available from the Quaternary or Pliocene sections at Site 955, so the quality of the model cannot be checked at this time. Dates, however, are available in the Miocene portion of the sequence based on correlation of syn-ignimbrite turbidites to well-dated landbased ignimbrites (Bogaard and Schmincke, Chap. 11; Sumita and Schmincke, Chap. 15; both this volume). Synignimbrite turbidites from middle Miocene lithostratigraphic Subunit IVB (equivalents of the X-ignimbrite, 548.32-548.38 mbsf, $13.8 \mathrm{Ma}$; P1 ignimbrite, 565.24-567.19 mbsf, 13.95 Ma; Shipboard Scientific Party, 1995c) were younger and deeper than four nearby bio- and magnetostratigraphic datum levels (Fig. 8; Table 3), suggesting that bio- and magnetostratigraphic control is poor in coarse volcanic deposits. Older microfossils might have been reworked into the younger volcanic material during transport and emplacement, and poor carbonate preservation caused by the shallow CCD of the middle Miocene may have made first occurrences too shallow. True first and last occurrences in the sediment column might have been eroded away during deposition of the volcaniclastics. Alternatively, the ages assigned to the datum levels may need revision (Schmincke and Sumita, Chap. 27, this volume), a suggestion supported by the fact that the last occurrences of Sphenolithus heteromorphus and Helicosphaera ampliaperta are slightly older than nearby radiometric samples, as they were at Site 953.

Sedimentation rates (Table 2) were grossly estimated using slopes of the model regression lines. Rates were slow during the Fataga eruptive period ( 25 to $68 \mathrm{~m} / \mathrm{m}$.y.), not detectably different during the major nonvolcanic phase (24 to $129 \mathrm{~m} / \mathrm{m} . \mathrm{y}$.), and perhaps somewhat faster (58-274 m/m.y.) during the Pliocene; however, large standard errors introduce considerable uncertainty. Rates were fast during the Quaternary, where a rate between 58 and $66 \mathrm{~m} / \mathrm{m}$.y. was estimated with confidence. Sedimentation rates were estimated from the regression equations at $95 \%$ confidence intervals. Wide ranges in rates suggest great stratigraphic uncertainty. 


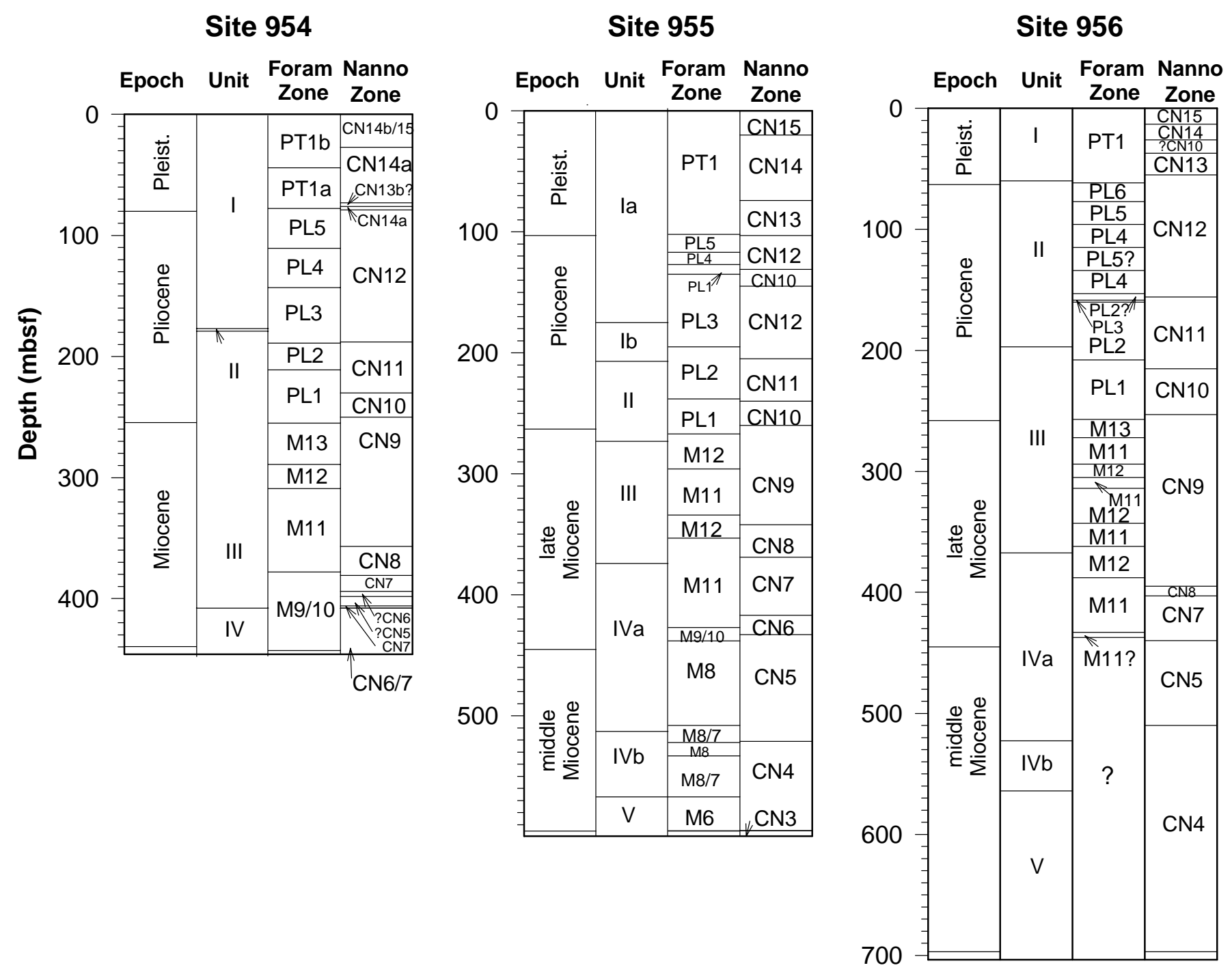

Figure 5. Correlation of foraminifer and calcareous nannofossil zones at Sites 954, 955, and 956.

\section{SITE 956}

Lithofacies are dominated by a clayey nannofossil mixed sediment interlayered with turbidites from both Gran Canaria and the adjacent African continental margin (Fig. 7). Extensive slumped intervals and debris flows comprise a minimum of $16 \%$ of the sequence, making it the most disturbed of the four sites from the Gran Canaria volcanic apron (Goldstrand, Chap. 20, this volume; Shipboard Scientific Party, 1995d). Several basalt lapillistones and quartz silt and sand beds amid clayey nannofossil mixed sediment are associated with an interval of poor recovery from 158.1 to 196.9 mbsf (lithologic Unit II). Numerous felsic volcaniclastic turbidites with minor basalt, phonolite, mud-clast breccia, lapillistones, and tuffaceous deposits are interbedded with nannofossil mixed sediments below 367.5 mbsf in the marine equivalents of the Fataga and Mogan eruptive stages (lithologic Unit IV). Coarse hyaloclastic tuffs, lapillistone, and breccia dominate the lithology below $564.1 \mathrm{mbsf}$ (lithologic Unit V).

The biostratigraphic sequence is highly disrupted by several large repeated sequences and hiatuses caused by extensive slumping (Fig. 5; Shipboard Scientific Party, 1995d). The early Pliocene Zone CN10 is recognized in a slumped interval between Quaternary Subzones $\mathrm{CN} 14 \mathrm{a}$ and CN13a at 32 to 33.26 mbsf, where Subzone CN13b was apparently removed by the slump. Pliocene Subzones CN12a and
$\mathrm{CN} 12 \mathrm{~b}$ are repeated two times between 92.00 and $141.20 \mathrm{mbsf}$ below their shallowest occurrence, and are associated with debris flows from 101 to $118 \mathrm{mbsf}, 127.6$ to $130 \mathrm{mbsf}$, and 139 to $140.9 \mathrm{mbsf}$ (Goldstrand, Chap. 20, this volume). The equivalent planktonic foraminifer Zones PL5 and PL4 are also repeated over this interval from 101.35 to 148.75 mbsf. The interval from 150.90 to $159.10 \mathrm{mbsf}$ contains abundant reworked Miocene nannofossils that obscure definitive zonal assignment, hence it was placed in undifferentiated Pliocene Zones CN12/CN11. The planktonic foraminifers suggest early Pliocene Zone PL2 at this latter depth, which lies out of sequence below PL4 and above PL3. Miocene Subzone CN9b is almost $100 \mathrm{~m}$ thick (256.61-354.31 mbsf), probably because of repeated intervals. The suspicion was confirmed by the repetition of planktonic foraminifer Zones M11 and M12 over a similar interval from 275.86 to 357.98 mbsf. Large debris flows occur throughout the interval.

Stratigraphic relationships are uncertain below 393 mbsf, although slumping is minor (Goldstrand, Chap. 20, this volume). A hiatus of 0.97 m.y. between 8.7-8.8 and 9.70-9.73 Ma may be present based on the simultaneous last occurrences of G. dehiscens, D. hamatus, and large $(>7 \mu \mathrm{m})$ R. pseudoumbilicus at $413.3 \mathrm{mbsf}$ and the absence of Subzone CN8a (Fig. 5). second hiatus of 1.23 m.y. between 9.76-9.86 and 11.01-11.06 Ma is suggested by the simultaneous first occurrences of $N$. acostaensis and G. nepenthes at $445.35 \mathrm{mbsf}$, and 


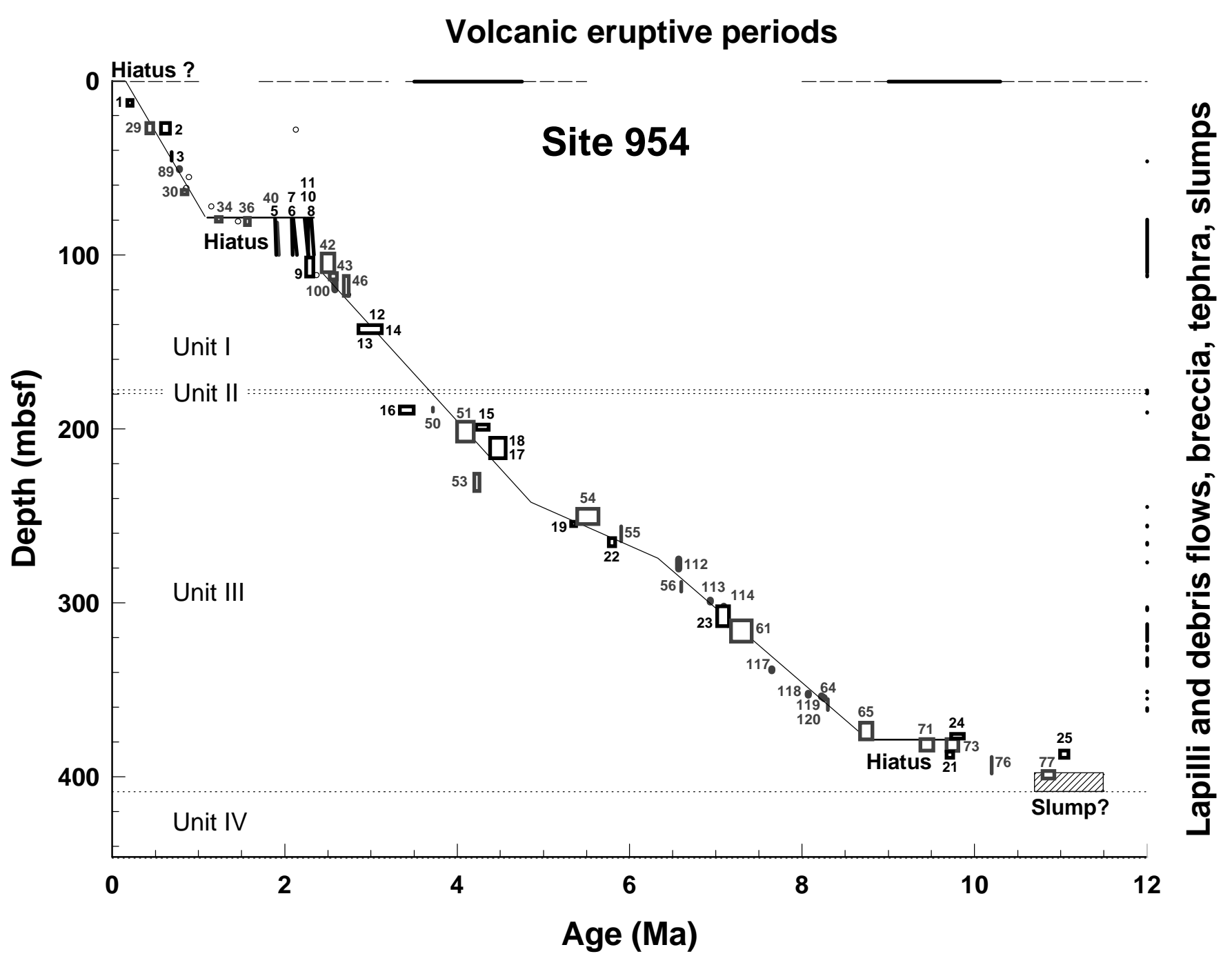

Figure 6. Age model of Site 954. The four thin-black-line segments are least square regression lines through local first and last occurrences of planktonic foraminifers and calcareous nannofossils, with age as the dependent variable and depth (mbsf) as the independent variable (Table 5). Ages of foraminifer datum levels are those estimated from the Site 953 age model, and the ages of nannofossil datum levels are those estimated by interpolation to an age-depth plot of paleomagnetic boundaries of Site 953 (Sblendorio-Levy and Howe, Chap. 8, this volume; see Tables 4 and 5). Each first and last occurrence is marked by a line indicating the stratigraphic error, the interval between the depth of the microfossil event and the depth of the adjacent sample where it is absent. The datum levels are coded by numbers that correspond to codes in Tables 4 and 5 . Horizontal black lines delimit hiatuses and slump blocks. The timing of volcanic eruptive periods on Gran Canaria is plotted on the secondary age axis, and the depths of lapillistones, debris flows, breccia, slumps, and other coarse-grained deposits are plotted on the secondary depth axis. The boundaries of the lithostratigraphic units are marked as dashed horizontal lines.

the last occurrence of Coccolithus miopelagicus at $446.30 \mathrm{mbsf}$. Zones M10, M9, and CN6 are missing, perhaps removed during creation of the disconformity. The proximity of the two disconformities, however, presents a problem. The section between the disconformities is $32 \mathrm{~m}$ thick deposited in only $\sim 0.1 \mathrm{~m}$.y. at a rate of $320 \mathrm{~m} / \mathrm{m}$.y., an improbable circumstance unsupported by the lithology. We cannot resolve the paradox at this time.

The polarity record at Site 956 was confounded by several problems, including severe slumping and magnetization acquired during drilling (Herr et al., Chap. 6, this volume). Although several boundaries were tentatively recognized during preliminary study (Shipboard Scientific Party, 1995d), only the Brunhes/Matuyama boundary at $\sim 34$ mbsf was used in this study.

An age model of Site 956 was compiled from the datum levels between slumped and reworked units (Fig. 9). The stratigraphy and chronology of the sequence below 400 mbsf are not clear, thus a sedimentation rate was not estimated between slumps and hiatuses, but rather, over the entire interval. This included the hiatuses and other disruptions to estimate a net sedimentation rate. The net sedimentation rate is only $22-32 \mathrm{~m} / \mathrm{m}$.y., reflecting the shortening of the sequence by disconformities despite volcaniclastic input from the Fataga eruptions (Table 2). We calculated the remainder of the model lines within biostratigraphically continuous sequences of sediment as in previous site models. The latest Miocene and Pliocene line segments of the model are shifted later in time and upsection relative to one another (opposite the effect of hiatuses), in response to the length added by repeated sequences between the line segments. Sedimentation rates are essentially the same in the two intervals, 36-48 m/m.y. and $37-58 \mathrm{~m} / \mathrm{m} . y$. , respectively. The offset between the late Pliocene and Quaternary segments indicated a hiatus from 0.78 to 1.39 to 1.41 Ma of $\sim 0.6$ m.y. between the Brunhes/Matuyama boundary and the last occurrence of Calcidiscus macintyrei (34 and $44.25 \mathrm{mbsf}$, respectively) at the base of a slumped interval of early Pliocene sediment. Uncertainties were too great to estimate a significant regres- 
Figure 7. Lithology vs. depth at Sites 955 and 956. The position and thicknesses of slumped intervals are indicated by black lines to the right of the lithologic columns.

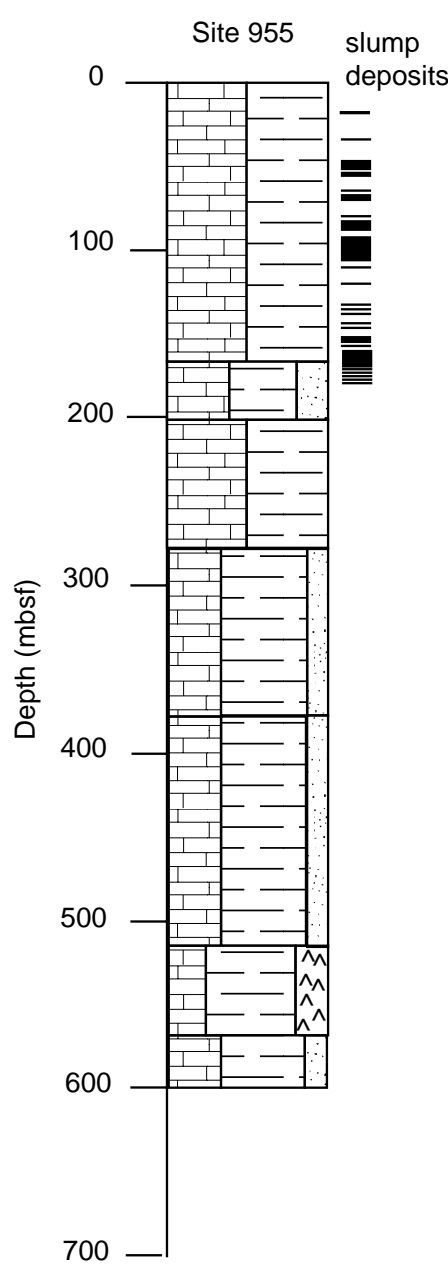

sion line in the upper Quaternary section. Sedimentation rates were estimated from the regression equations at $95 \%$ confidence interval.

The late Pliocene model line was compared to nine radiometric dates (Bogaard, Chap. 19, this volume; Table 3; Fig. 9). The radiometric dates fall within twice the standard error of the estimate for the late Pliocene model regression line (Table 2). The late Pliocene sedimentation rate estimated from the radiometric dates was $59 \mathrm{~m} / \mathrm{m}$.y., within the $97.5 \%$ confidence interval of the rate estimated from biostratigraphic data. In contrast, the age of the middle Miocene P1 ignimbrite was younger and deeper than the general trend of biostratigraphic datum levels, suggesting either that biostratigraphic control in coarse lithostratigraphic subunits, like Subunit IVB, is unreliable as it was in coarse-grained facies at the other Gran Canaria sites or that the ages of biostratigraphic and magnetostratigraphic datum levels are too old and need revision (Schmincke and Sumita, Chap. 27, this volume).

\section{COMPARISON OF MODEL RESULTS}

None of the sequences at Sites 953 to 956 is continuous, and all have disconformities. The sequence at Site 953, however, is affected to only a minor degree by comparatively brief hiatuses (Table 6). The models conveniently show that hiatuses grouped $\sim 9.8 \mathrm{Ma}$ (Sites 953 and 956), 8.8 Ma (Sites 954, 955, and 956), 5.5 Ma (Site 955), $4 \mathrm{Ma}$ (Sites 953 and 955), 1 to $3 \mathrm{Ma}$ (Sites 954, 955, and 956), and the tops of the sequences at Sites 953 and 954 (Fig. 10, Table 6). The hiatuses were generally associated with slumps, which resulted in net shortening of the sections (i.e., two examples marked on Fig. 6 of Site
954), whereas some slumps lengthened the stratigraphic sections by repeating intervals (i.e., examples marked on Fig. 9 of Site 956). Hiatuses are associated in time with several volcanic eruptive periods: a cluster of hiatuses during the younger maxima of the Fataga eruptive period, one during the pre-Roque Nublo eruptive period, and two during the Roque Nublo eruptive period. Hiatuses also occur during the Late Pliocene and Quaternary Epochs when changes in sea level were large and sporadic volcanic eruptions occurred. It is interesting to note that inflection points, where sedimentation rates changed without disconformities, tended to occur in time periods frequented by hiatuses (Figs. 10, 11).

The models (Fig. 11; Table 2) highlight sections where no disconformities could be detected by the bio- and magnetostratigraphies. The continuous sections had constant average sedimentation rates ranging from $\sim 20$ to $\sim 90 \mathrm{~m} / \mathrm{m}$.y. over time periods ranging from 0.9 to $4 \mathrm{~m}$.y. The rates and periods are typical for calcareous oozes and chalk (Sadler and Strauss, 1990). In reality, however, the sequences are filled with turbidites (typically $40 \%-60 \%$ of most 10 -m cores) interspersed with more slowly accumulating nannofossil mixed sediments, so that short-term sedimentation rates must have been highly unsteady, accelerating and decelerating over periods of time shorter than the biostratigraphic resolution. At Sites 953, 954, and the Quaternary of Site 955 , where datum levels were most linear, the unsteadiness of the sedimentation rate is on a smaller time scale than at Site 956 and most of Site 955, where datum levels show more scatter about model regression lines (Table 2). The quality (breadth of the $95 \%$ confidence interval) of the sedimentation rate estimates is variable, changing with sample sizes and standard errors of the model regression slopes. Table 2 includes a confidence interval of $95 \%$ for 


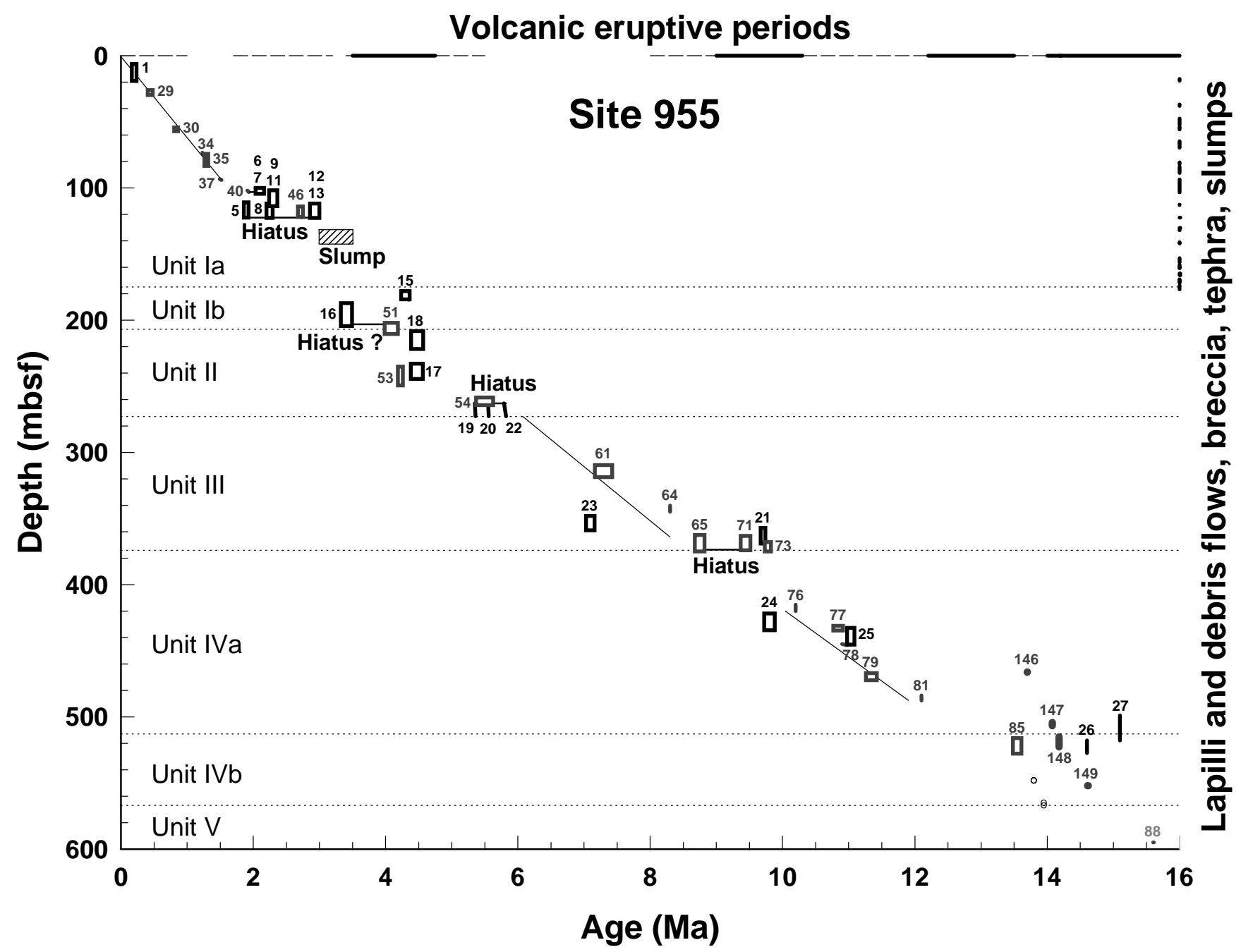

Figure 8. Age model of Site 955. The three thin-black-line segments are least square regression lines through first and last occurrences planktonic foraminifers and calcareous nannofossils with age as the dependent variable and depth as the independent variable (Table 5). Ages of foraminifer datum levels are those estimated from the Site 953 age model, and the ages of nannofossil datum levels are those estimated by interpolation to an age-depth plot of paleomagnetic boundaries of Site 953 (Sblendorio-Levy and Howe, Chap. 8, this volume; see Tables 3 and 4). Each first and last occurrence is marked by a line indicating the stratigraphic error, the interval between the depth of the microfossil event, and the depth of the adjacent sample where it is absent. The datum levels are coded by numbers that correspond to codes in Tables 4 and 5. Horizontal black lines delimit hiatuses and slump blocks. The timing of volcanic eruptive periods on Gran Canaria is plotted on the secondary age axis, and the depths of lapillistones, debris flows, breccia, slumps and other coarse-grained deposits are plotted on the secondary depth axis. The boundaries of the lithostratigraphic units are marked as dashed horizontal lines.

each sedimentation rate, and demonstrates that Site 953 rate estimates were generally superior (narrow confidence interval) to those at the other sites.

The ability of the models to estimate ages can be evaluated in several ways, including by inspection of the standard error of the estimated ages at each point around the model lines. The standard errors of the age estimates, where age is the dependent variable and depth is the independent variable of the regression model, are functions of the error of prediction of individual ages at selected depths. The standard errors ranged from \pm 0.05 m.y. to a dreadful \pm 0.6 m.y., which is marginally useful. In general, Site 953 was superior to the other sites by all measures, followed by Site 954.

In light of the preceding evaluation, it is clear that the records at the sites have varied and limited ability to resolve events in geologic time. What time scales can be usefully resolved? It can be argued that samples must be spaced wider than twice the standard error to be significantly different in age, so minimum sample periods must be $\sim 0.1$ m.y. or longer. Because four samples per cycle are needed to delimit cyclic environmental events (Ledbetter and Ellwood, 1976), then cycles of 0.4 m.y. or longer can be resolved in the best sequences from the Canary Island apron. This is adequate to resolve the broad highs and lows of volcanic activity since the early Miocene, third-order sea-level changes, and broad environmental cycles, possibly even 0.4-m.y Milankovitch cycles, but it is inadequate to resolve shorter cycles, like fourth-order sea-level changes, unless the models can be improved. The models might be improved, for example, by reducing the stratigraphic error of biostratigraphic datum levels.

\section{CONCLUSIONS}

1. The sequence at Site 953 is the most stratigraphically continuous, the steadiest in deposition rate, and the finest in age resolution of all the sequences from the volcanic apron of Gran Canaria. It contains sediment from most middle Miocene to Quaternary bio- and magnetostratigraphic zones, and is inter- 


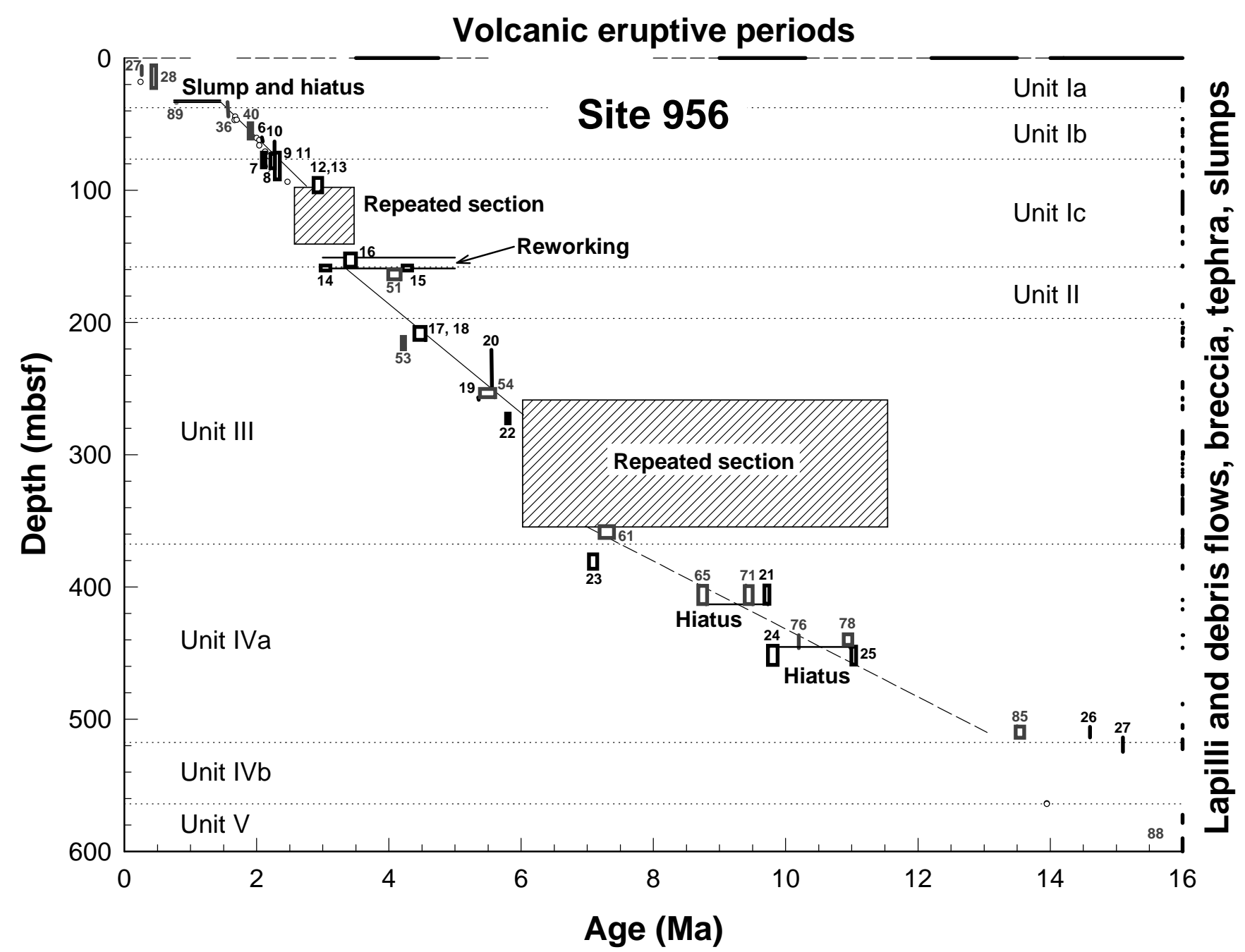

Figure 9. Age model of Site 956. The three thin-black-line segments are least square regression lines through first and last occurrences planktonic foraminifers and calcareous nannofossils with age as the dependent variable and depth as the independent variable (Table 5). The deepest regression line (dashed) is drawn through two hiatuses, which represents net sedimentation rate in a demonstrably shortened sequence. Ages of foraminifer datum levels are those estimated from the Site 953 age model, and the ages of nannofossil datum levels are those estimated by interpolation to an age-depth plot of paleomagnetic boundaries of Site 953 (Sblendorio-Levy and Howe, Chap. 8, this volume; see Tables 3 and 4). Each first and last occurrence is marked by a line marking the stratigraphic error, the interval between the depth of the microfossil event and the depth of the adjacent sample where it is absent. The datum levels are coded by numbers that correspond to cjodes in Tables 4 and 5. Horizontal black lines delimit hiatuses and slump blocks, and repeated intervals are delimited by a diagonal dashed line. The timing of volcanic eruptive periods on Gran Canaria is plotted on the secondary age axis, and the depths of lapillistones, debris flows, breccia, slumps and other coarse-grained deposits are plotted on the secondary depth axis. The boundaries of the lithostratigraphic units are marked as dashed horizontal lines.

rupted by only three short hiatuses, none of which is longer than 0.4 m.y.

2. Local ages of foraminifer and calcareous nannofossil first and last occurrences were estimated from magnetostratigraphy of the sequence at Site 953. Local ages of the first and last occurrences of most species do not differ significantly from the global/oceanwide ages of Berggren et al. (1995a, 1995b), except those of 9 species: the last occurrence of $G$. dehiscens $(4.1$ m.y. older than expected), the first occurrence of $N$. acostaensis (1.1 m.y. younger), the first occurrence of $G$. nepenthes (0.77 m.y. younger), the last occurrence of D. loeblichii $(0.3$ m.y. younger), the first occurrence of $D$. berggrenii ( 0.3 m.y. younger), the first occurrence of $M$. convallis ( 0.25 m.y. older), the first occurrence of $D$. hamatus ( 0.75 m.y. younger), the first occurrence of $D$. coalitus $(0.45 \mathrm{~m}$.y. younger $)$, and the first occurrence of D. kugleri (0.3 m.y. older).
3. Hiatuses at the four sites generally group within four periods: the late Fataga eruptive period; the pre-Roque Nublo eruptive period; the Roque Nublo eruptive period; and the late Pliocene and Quaternary Epochs, when changes in sea level were large and volcanic eruptions were sporadic on Gran Canaria.

4. Least squares linear regression was used successfully to calculate age models of sediment accumulation at Sites 953, 954, 955 , and 956 over 20 intervals that were continuous within the time and depth resolutions of the magnetostratigraphy and/or the biostratigraphies. Eight intervals from Sites 953, 954, and 955 have standard errors of the age estimate $<0.13$ m.y., and five intervals have errors $<0.10 \mathrm{~m}$.y. Radiometric dates of selected volcaniclastic samples were compared to ages predicted by the models as an independent measure of model accuracy. The radiometric dates are within the standard errors of the age estimate of the associated model lines. 
Table 6. Timing of hiatuses recognized at Sites 953, 954, 955, and 956.

\begin{tabular}{|c|c|c|c|c|c|}
\hline $\begin{array}{l}\text { Model hiatus age } \\
\text { (Ma) }\end{array}$ & Top datum level & Bottom datum level & $\begin{array}{l}\text { Ages of datum levels } \\
\text { (Ma) }\end{array}$ & $\begin{array}{c}\text { Duration } \\
\text { (m.y.) }\end{array}$ & $\begin{array}{l}\text { Depth } \\
\text { (mbsf) }\end{array}$ \\
\hline $\begin{array}{l}0.0-0.20 \\
3.74-4.36 \\
9.98-10.75\end{array}$ & $\begin{array}{l}\text { Core top } \\
\text { FO Gr. miocenica } \\
\text { C5n.2n (top) }\end{array}$ & $\begin{array}{l}\quad \text { Site } 953 \\
\text { FO Gg. calida calida } \\
\text { LO Gg. nepenthes } \\
\text { FO D. hamatus }\end{array}$ & $\begin{array}{l}0.0 \text { to } 0.2-0.22 \\
4.24-4.35 \text { to } 4.41-4.55 \\
9.82 \text { to } 10.2\end{array}$ & $\begin{array}{l}0.21 \\
0.19 \\
0.38\end{array}$ & $\begin{array}{c}0.0 \text { to } 1.3 \\
264.11 \text { to } 264.82 \\
505.90 \text { to } 516.07\end{array}$ \\
\hline $\begin{array}{l}0.0-0.16 \\
1.07-2.43 \\
8.88-9.75\end{array}$ & $\begin{array}{l}\quad- \\
\text { FO R. asanoi } \\
\text { LO common } \\
\text { R. pseudoumbilicus } \\
\text { CN6/7 }\end{array}$ & $\begin{array}{l}\quad \frac{\text { Site } 954}{-} \\
\text { LO D. surculus } \\
\text { FO M. convallis } \\
\text { M7 }\end{array}$ & $\begin{array}{l}\text { - } \\
\text { 1.23-1.25 to } 2.55-2.59 \\
8.87-8.8 \text { to } 9.7-9.8\end{array}$ & $\begin{array}{l}0.16 \\
1.33 \\
1.00 \\
\sim 4\end{array}$ & $\begin{array}{c}0 \\
77.32 \text { to } 109.7 \\
377.83 \text { to } 379.83 \\
408\end{array}$ \\
\hline $\begin{array}{l}1.51-2.93 \\
\overline{5.56-6.07} \\
8.30-10.04\end{array}$ & $\begin{array}{l}\text { LO Gn. extremus } \\
\text { LO Gr. margaritae } \\
\text { FO Gr. tumida } \\
\text { LO D. hamatus }\end{array}$ & $\begin{array}{l}\quad \text { Site } 955 \\
\text { LO Gr. mulitcamerata } \\
\text { FO common D. tamalis } \\
\text { FO Gr. margaritae } \\
\text { LO } R \text {. pseudoumbilicus }\end{array}$ & $\begin{array}{l}1.89-1.90 \text { to } 2.88-2.97 \\
3.36-3.48 \text { to } 4.02-4.17 \\
5.55-5.56 \text { to } 5.79-5.82 \\
8.7-8.8 \text { to } 9.4-9.5\end{array}$ & $\begin{array}{l}1.03 \\
0.68 \\
0.25 \\
0.70\end{array}$ & $\begin{array}{l}93.6 \text { to } 122.29 \\
203.57 \\
262.87 \\
373.60\end{array}$ \\
\hline $\begin{array}{c}0.78-1.37 \\
-\end{array}$ & $\begin{array}{l}\text { Matuyama (top) } \\
\text { LO D. hamatus } \\
\text { FO Nq. acostaensis }\end{array}$ & $\begin{array}{l}\text { Site } 956 \\
\text { LO } C . \text { macintyrei } \\
\text { LO Gq. dehiscens } \\
\text { FO Gg. nepenthes }\end{array}$ & $\begin{array}{l}0.78 \text { to } 1.39-1.41 \\
8.7-8.8 \text { to } 9.70-9.73 \\
9.76-9.88 \text { to } 11.01-11.06\end{array}$ & $\begin{array}{l}0.62 \\
0.97 \\
1.23\end{array}$ & $\begin{array}{l}34.0 \text { to } 44.25 \\
413.3 \\
446.30\end{array}$ \\
\hline
\end{tabular}

Note: $-=$ not calculated

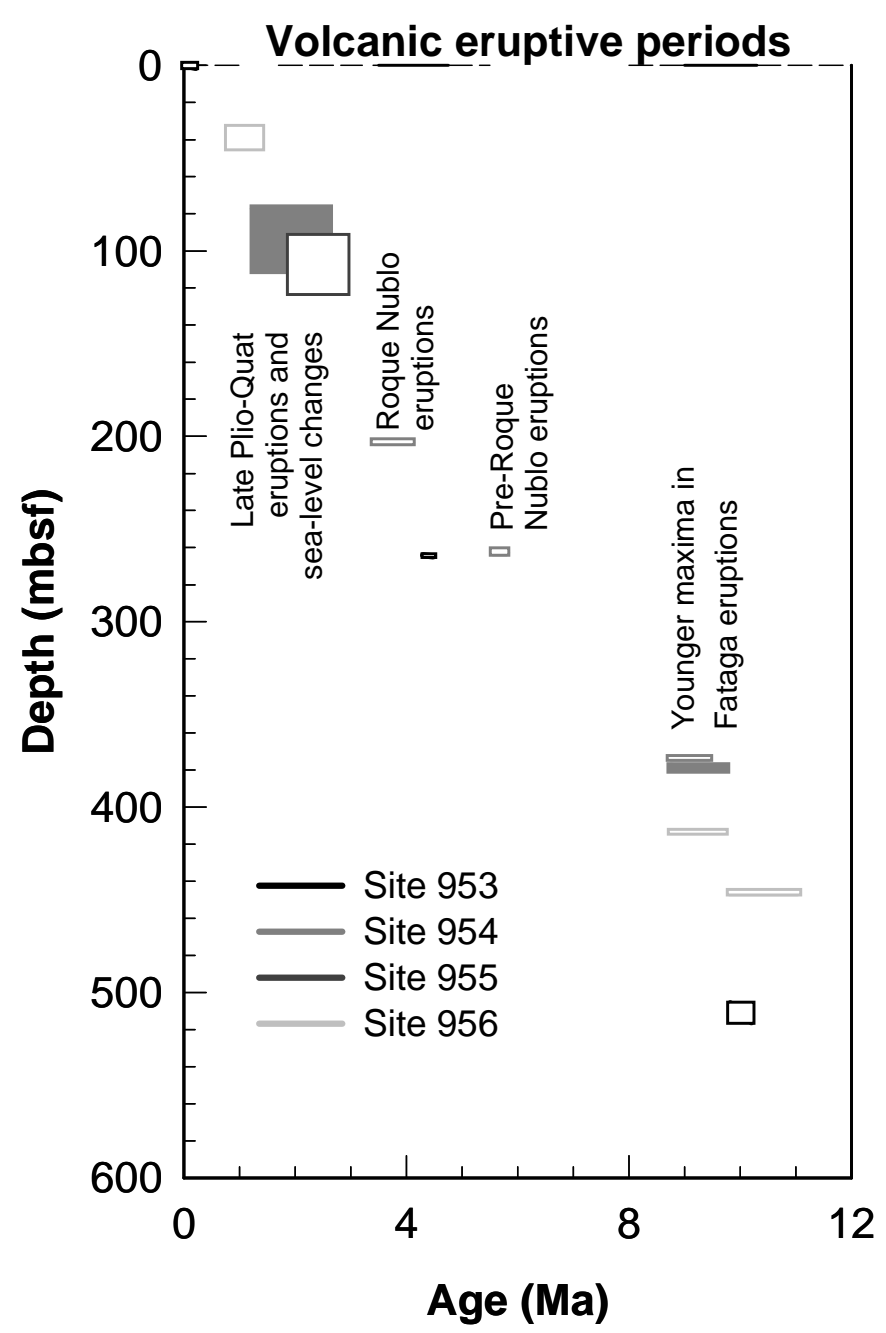

Figure 10. Hiatuses at Sites 953, 954, 955, and 956 plotted as age vs. depth. The timing of volcanic eruptive periods on Gran Canaria is plotted on the secondary age axis. Note that hiatuses tend to cluster around the younger maxima in Fataga eruption between 8 and $9 \mathrm{Ma}$, around the Roque Nublo eruptive period, and in the late Pliocene to Quaternary.
5. The time resolution of sequences at Site 953 and portions of the sequences at Site 954 and 955 is adequate to resolve the broad highs and lows of volcanic activity since the early Miocene third-order sea-level changes, broad environmental cycles, and possibly even 0.4-m.y. Milankovitch cycles.

\section{ACKNOWLEDGMENTS}

We gratefully acknowledge the data, results, and many fruitful discussions shared with our Leg 157 colleagues, and the thoughtful reviews of the manuscript by Dr. Hans-Ulrich Schmincke, Dr. John Barron, and an anonymous reviewer. We commend the ODP science staff and the Sedco crew of the JOIDES Resolution, whose expertise and competence made Leg 157 a success. The research was supported in part by grants from Joint Oceanographic Institutions U.S. Science Support Program to C. Brunner, J. Sblendorio-Levy, M. Fuller, and P. Goldstrand, and, in part, by a Consiglio Nazionale delle Ricerche grant to R. Maniscalco for postdoctoral studies at the Istituto di Geologia Marina, Consiglio Nazionale delle Ricerche, Bologna. R. Howe was supported by the European Commission on Marine Science and Technology (MAST II) programme (Sediment Transport on European Atlantic Margins [STEAM] Project, grant MAS2-CT940083), and P. Bogaard by a grant from the Deutsche Forschungsgemeinschaft (Grant No. DFG Bo 912/4-1). (Institute of Marine Sciences Contribution Number 0187).

\section{REFERENCES}

Berger, W.H., and von Rad, U., 1972. Cretaceous and Cenozoic sediments from the Atlantic Ocean. In Hayes, D.E., Pimm, A.C., et al., Init. Repts. DSDP, 14: Washington (U.S. Govt. Printing Office), 787-954.

Berger, W.H., and Winterer, E.L., 1974. Plate stratigraphy and the fluctuating carbonate line. In Hsü, K.J., and Jenkyns, H.C. (Eds.), Pelagic Sediments on Land and Under the Sea. Spec. Publ. Int. Assoc. Sedimentol., 1:1148.

Berggren, W.A., Hilgen, F.J., Langereis, C.G., Kent, D.V., Obradovich, J.D., Raffi, I., Raymo, M.E., and Shackleton, N.J., 1995a. Late Neogene chronology: new perspectives in high-resolution stratigraphy. Geol. Soc. Am. Bull., 107:1272-1287.

Berggren, W.A., Kent, D.V., Swisher, C.C., III, and Aubry, M.-P., 1995b. A revised Cenozoic geochronology and chronostratigraphy. In Berggren, W.A., Kent, D.V., Aubry, M.-P., and Hardenbol, J. (Eds.), Geochronol- 
ogy, Time Scales and Global Stratigraphic Correlation. Spec. Publ.Soc. Econ. Paleontol. Mineral., 54:129-212.

Cande, S.C., and Kent, D.V., 1995. Revised calibration of the geomagnetic polarity timescale for the Late Cretaceous and Cenozoic. J. Geophys. Res., 100:6093-6095.

Dowsett, H.J., 1989. Application of the graphic correlation method to Pliocene marine sequences. Mar. Micropaleontol., 14:3-32.

Heath, G.R., 1969. Carbonate sedimentation in the abyssal equatorial Pacific during the past 50 million years. Geol. Soc. Am. Bull., 80:689-694.

Ledbetter, M.T., Ellwood, B.B., 1976. Selection of sample intervals in deepsea sedimentary cores. Geology, 4:303-304.

McDougall, I., and Schmincke, H.-U., 1977. Geochronology of Gran Canaria, Canary Islands: age of shield-building volcanism and other magmatic phases. Bull. Volcanol., 40:1-21.

Ramsay, A.T.S., 1977. Sedimentological clues to paleoceanography. In Ramsay, A.T.S. (Ed.), Oceanic Micropaleontology (Vol. 2): New York (Academic Press), 1371-1453.

Sadler, P.M., Strauss, D.J., 1990. Estimation of completeness of stratigraphical sections using empirical data and theoretical models. J. Geol. Soc. London, 147:471-485.

Schmincke, H.-U., 1967. Cone sheet swarm, resurgence of Tejeda caldera, and the early geologic history of Gran Canaria. Bull. Volcanol., 31:153162 .

, 1969. Ignimbrite sequence on Gran Canaria. Bull. Volcanol., 33:1199-1219.

, 1976. The geology of the Canary Islands. In Kunkel, G. (Ed.), Biogeography and Ecology in the Canary Islands: The Hague (W. Junk), 67-184.

, 1982. Volcanic and chemical evolution of the Canary Islands. In von Rad, U., Hinz, K., Sarnthein, M., and Seibold, E. (Eds.), Geology of the Northwest African Continental Margin: Berlin (Springer), 273-306.

, 1994. Geological Field Guide: Gran Canaria (6th ed.): Kiel, Germany (Pluto Press).

Schmincke, H.-U., and von Rad, U., 1979. Neogene evolution of Canary Island volcanism inferred from ash layers and volcaniclastic sandstones of DSDP Site 397 (Leg 47A). In von Rad, U., Ryan, W.B.F., et al., Init. Repts. DSDP, 47 (Pt. 1): Washington (U.S. Govt. Printing Office), 703725 .
Shackleton, N.J., Crowhurst, S., Hagelberg, T., Pisias, N.G., and Schneider, D.A., 1995. A new late Neogene time scale: application to Leg 138 sites. In Pisias, N.G., Mayer, L.A., Janecek, T.R., Palmer-Julson, A., and van Andel, T.H. (Eds.), Proc. ODP, Sci. Results, 138: College Station, TX (Ocean Drilling Program), 73-101.

Shipboard Scientific Party, 1995a. Site 953. In Schmincke, H.-U., Weaver, P.P.E., Firth, J.V., et al., Proc. ODP, Init. Repts., 157: College Station, TX (Ocean Drilling Program), 317-394.

, 1995b. Site 954. In Schmincke, H.-U., Weaver, P.P.E., Firth, J.V., et al., Proc. ODP, Init. Repts., 157: College Station, TX (Ocean Drilling Program), 395-431.

1995c. Site 955. In Schmincke, H.-U., Weaver, P.P.E., Firth, J.V., et al., Proc. ODP, Init. Repts., 157: College Station, TX (Ocean Drilling Program), 433-496.

, 1995d. Site 956. In Schmincke, H.-U., Weaver, P.P.E., Firth, J.V., et al., Proc. ODP, Init. Repts., 157: College Station, TX (Ocean Drilling Program), 497-557.

Staudigel, H., and Schmincke, H.-U., 1984. The Pliocene seamount series of La Palma/Canary Islands. J. Geophys. Res., 89:11195-11215.

Thunell, R.C., 1981. Late Miocene-early Pliocene planktonic foraminiferal biostratigraphy and paleoceanography of low latitude marine sequences. Mar. Micropaleontol., 6:71-90.

van Andel, T.H., 1975. Mesozoic/Cenozoic calcite compensation depth and the global distribution of calcareous sediments. Earth Planet. Sci. Lett., 26:187-194.

van Andel, T.H., Heath, G.R., and Moore, T.C., Jr., 1975. Cenozoic history and paleoceanography of the central equatorial Pacific Ocean: a regional synthesis of Deep Sea Drilling Project data. Mem.-Geol. Soc. Am., 143.

van Andel, T.H., and Moore, T.C., Jr., 1974. Cenozoic calcium carbonate distribution and calcite compensation in the central equatorial Pacific Ocean. Geology, 2:87-92.

Initial date of receipt: 17 January 1997

Date of acceptance: 9 April 1997

Ms 157SR-108

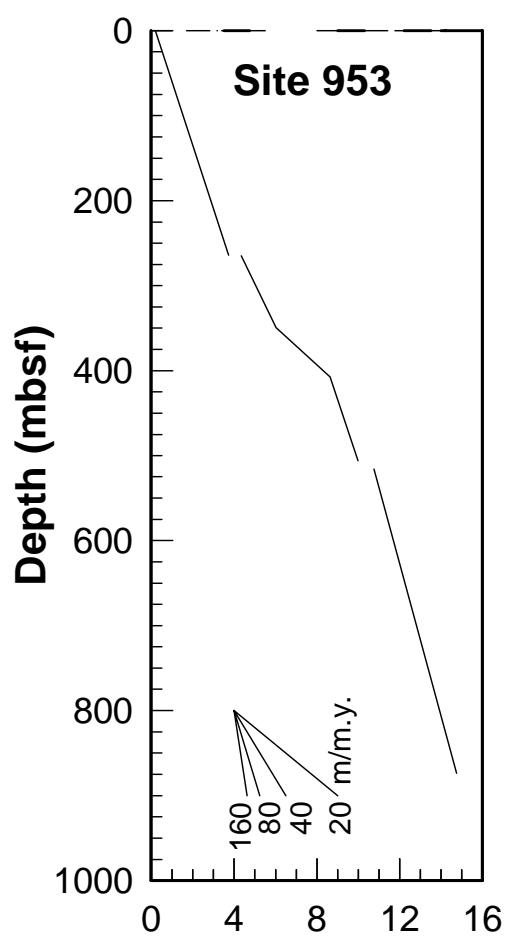

Volcanic eruptive periods
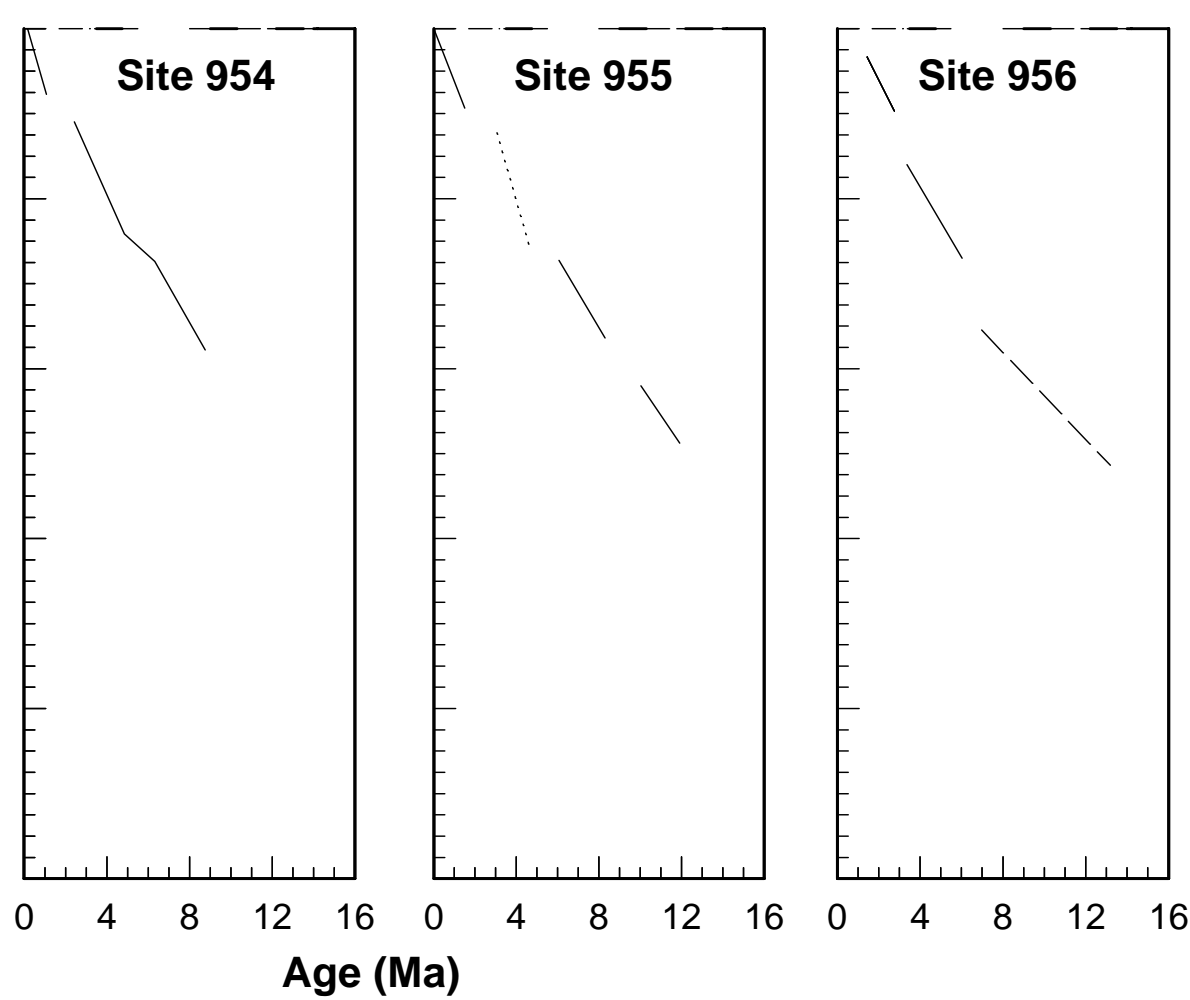

Figure 11. Comparison of age models at Sites 953, 954, 955, and 956. The timing of volcanic eruptive periods on Gran Canaria is plotted on the secondary age axis. 